\title{
Development/Ripening of Ecosystems Services in the First Two Growing Seasons of a Regional-Scale Constructed Stormwater Wetland on the Coast of North Carolina
}

Merriman, L.S. ${ }^{* 1}$, Hunt, W.F. ${ }^{2}$, Bass, K.L. ${ }^{3}$

\begin{abstract}
A well-functioning constructed stormwater wetland (CSW) will provide many ecosystem services. However, there has not been an effort to monitor and evaluate these services as a CSW develops in the first years after construction - the 'ripening' period. In this study, ecosystem services development was assessed during the first two growing seasons of a CSW located on the coast of North Carolina. The CSW research site was a regional-scale stormwater project with two different flow regimes: event and base flow. The full potential of some ecosystem services of this CSW were realized immediately such as volume reduction, TSS and $\mathrm{NO}_{2,3}$ treatment. Others were fully developed after the $1^{\text {st }}$ growing season, e.g. TAN, ON, TN, and TP treatment. Mostly, ripening of the CSW was complete, as areal C densities exceeded median C densities observed in other stormwater wetlands, and vegetation biodiversity measurements aligned with other stormwater wetlands in North Carolina, just one year after construction. The establishment of vegetation was deemed the most important design goal during this vital period, as vegetation is interlinked with other services: evapotranspiration, water quality improvement, and $\mathrm{C}$ input to the soil.
\end{abstract}

Keywords: Ecosystem Services, Stormwater Management, Constructed Stormwater Wetlands, Carbon Sequestration, Biodiversity, Water Quality

\footnotetext{
${ }^{1}$ National Science Foundation Graduate Research Fellow, North Carolina State University, Biological and Agricultural Engineering Department.

*Corresponding Author: laura.merriman@amecfw.com. 9177 Sky Park Court, San Diego, CA 92123

${ }^{2}$ William Neal Reynolds Distinguished Professor, North Carolina State University, Biological and Agricultural Engineering Department, Campus Box 7625 Raleigh, North Carolina 27695. Email: wfhunt@ncsu.edu

${ }^{3}$ Founder, Kris Bass Engineering. Email: kbass@kbeng.org
} 


\section{Introduction}

Negative ecological effects of stormwater runoff are of increasing concern, especially in areas of rapid urbanization. Federal, state, and local programs have been developed to mitigate the effects of runoff, many of which require the implementation of stormwater control measures (SCMs) (NC Administrative Code, 2008; MDE, 2015). These SCMs, such as constructed stormwater wetlands (CSWs), wet ponds, and bioretention cells, are typically designed to retain a specific water quality event, and then slowly release it (NCDENR, 2009). Constructed stormwater wetlands have become popular SCMs in low-lying coastal environments, offering a hybrid between larger detention practices (wet ponds) and newer green infrastructure technologies. The main characteristics of CSWs, such as shallow water (low marsh) depth, emergent vegetation, and the use of in situ soils, mimic those found in natural wetland ecosystems (Harrington et al., 2005). A well-functioning CSW will provide a diverse ecosystem that includes many plants and animals. These diverse ecosystems can provide services to society (Moore and Hunt, 2012), hence the term: ecosystem services (Costanza et al., 1997; MEA, 2005). These services include but are not limited to: provisioning services (food and raw materials), regulating services (water quality, peak flow mitigation), and cultural services (recreation and education) (De Groot, 2006; MEA, 2005). Regulating services, such as water quality and peak flow mitigation, of CSWs have been, understandably, the primary focus for evaluation and research, but these systems also offer biodiversity, carbon sequestration, and educational and recreational features (Moore and Hunt, 2012; Greenway, 2010; Anderson and Mitsch, 2006; Bolund and Hunhammar, 1999). Previous studies have demonstrated the first years after construction, the 'ripening' period, to be vital and highlighted two key maintenance and design mistakes that can affect the development of 
ecosystem services: (1) setting a normal pool elevation too deep and (2) clogging of the outlet structure, which artificially raises the normal pool elevation for extended periods of time (Greenway et al., 2007; Hunt et al., 2011). Greenway et al. (2007) observed poor vegetation survival due to extended periods of inundation and deeper water levels - transforming this CSW into a wet pond just 5 years after construction. Hunt et al. (2011) appraised a CSW in eastern North Carolina with high water levels shortly after construction due to an absent outlet orifice, and the CSW was transformed into a wet pond just 1.5 years after construction. Vegetation loss detrimentally impacted water treatment by CSWs as vegetation supports several pollutant removal mechanisms: filtration of particles, stabilization of sediments, nutrient uptake, microbial-rhizosphere interaction to promote nitrification and denitrification, and the provision of increased surface area for biofilm/periphyton growth (Greenway 2004). These pollutant removal mechanisms set CSWs apart from wet ponds. Loss of vegetation and prolonged periods of stagnant water can also lead to a loss in healthy macroinvertebrate communities and increased mosquito populations (Greenway, 2003; Hunt et al., 2006).

In this study, ecosystem services development was assessed during the first two growing seasons of a CSW located on the coast of North Carolina. The influent for this CSW is pumped only with event and base flow regimes. The site has a contributing watershed area of 621 ha and a footprint of approximately 7 ha. This design and scope is unique as most CSWs have catchments and CSW surface areas less than 80 ha and 2 ha, respectively. (Pier et al., 2015; Hathaway and Hunt, 2010; Wadzuk et al., 2010; Line et al., 2008).

The objective of this study was to assess ecosystem service development during the 'ripening' period of a regional-scale CSW with two flow regimes: event and base flow. These ecosystem 
service assessments focused on regulation services: hydrologic regulation and water quality improvement but also ancillary services such as vegetative biodiversity, which was second only to flood control in a review of the general public's value of services provided by constructed wetlands (Ghermandi et al., 2010), and carbon sequestration - a topic gaining international attention due to interest in regulating atmospheric carbon dioxide. The CSW design features that promoted or inhibited service development were also noted.

\section{Materials and Methods}

\section{Site Description}

The Jack Smith Creek constructed stormwater wetland (CSW) was located in the coastal plain of North Carolina and Neuse River Basin in the city of New Bern ( $35^{\circ} 07^{\prime} 26^{\prime \prime} \mathrm{N}, 77^{\circ} 03^{\prime} 50^{\prime \prime}$ W). The CSW earth and concrete work were completed in January 2013, planted in April and May 2013, and full construction was complete and operation commenced in June 2013. The CSW serviced a 621 ha watershed, $48 \%$ of which was impervious (Figure 1). The composite curve number for the watershed was estimated to be 82 . Soils in the watershed were mostly Arapahoe fine sandy loam (NRCS, 2013). 


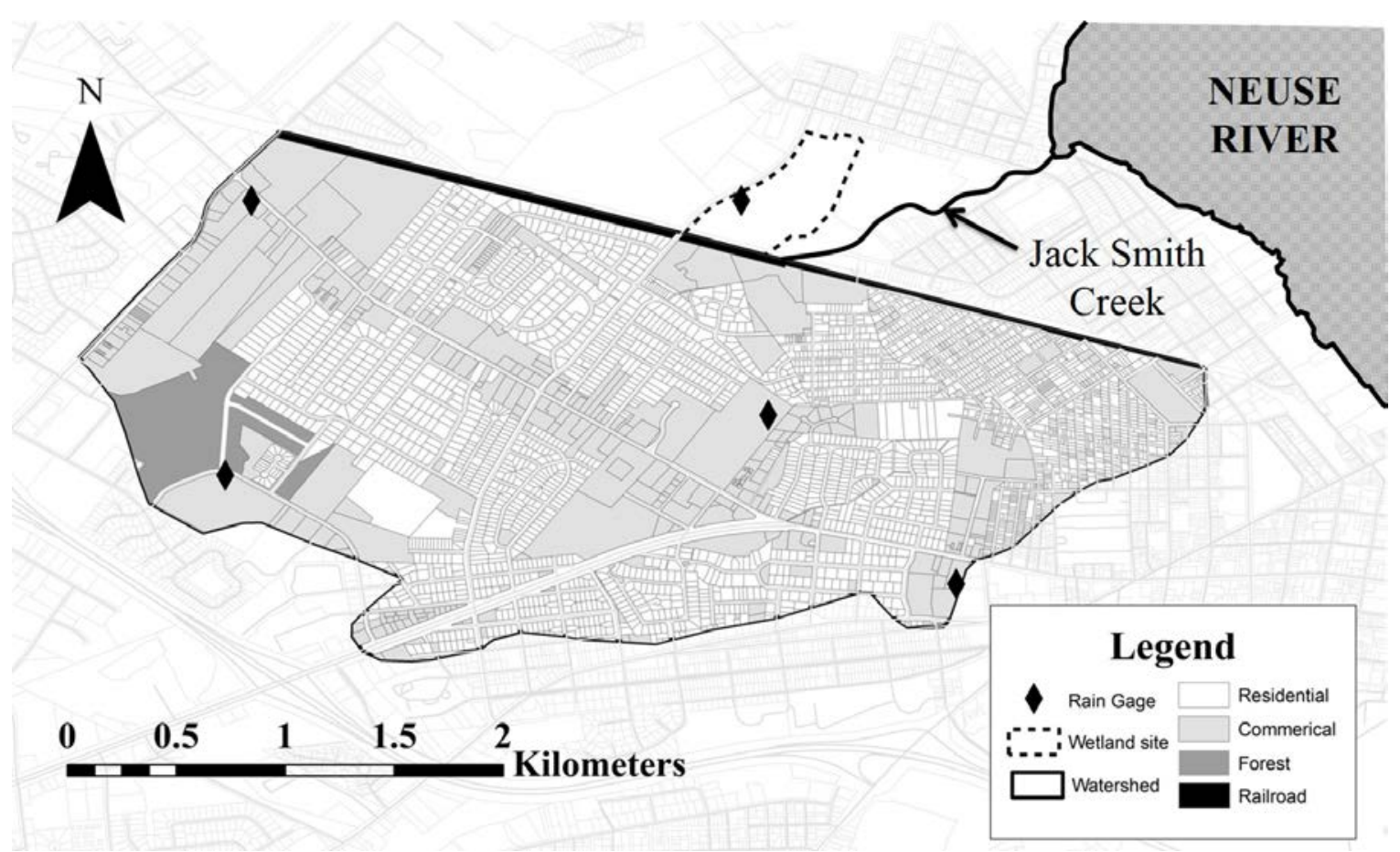

Figure 1: Jack Smith Creek CSW contributing watershed and installed rain gage locations in New Bern, North Carolina, USA

Prior to construction of the CSW, Jack Smith Creek was prone to flood many low-lying residential areas in the city due to very low hydraulic gradient in this area and tidal influences on the receiving water body: the Neuse River. A pump station was constructed to pump nearly all creek water to the CSW, which then discharged back to the creek and flowed to the Neuse River, 1.2 kilometers away (Figure 1). This CSW was comprised of multiple cells and had two inlets with one outlet (Figure 2). One influent source was a smaller, electric pump (3785 lpm) that ran daily and controlled base flow and storm events less than $25 \mathrm{~mm}$. The second influent source was a larger, diesel pump $(75,700 \mathrm{lpm})$ that controlled high creek stage from storm events larger than $25 \mathrm{~mm}$. The CSW was specifically designed to maintain necessary water depths and velocities to support wetland vegetation and maximize water quality improvements (Greenway, 2004; Greenway et al., 2007). The design included a mixture of deep pools, channels, islands, 
and densely vegetated zones, which mix water and habitats to promote ecological balance.

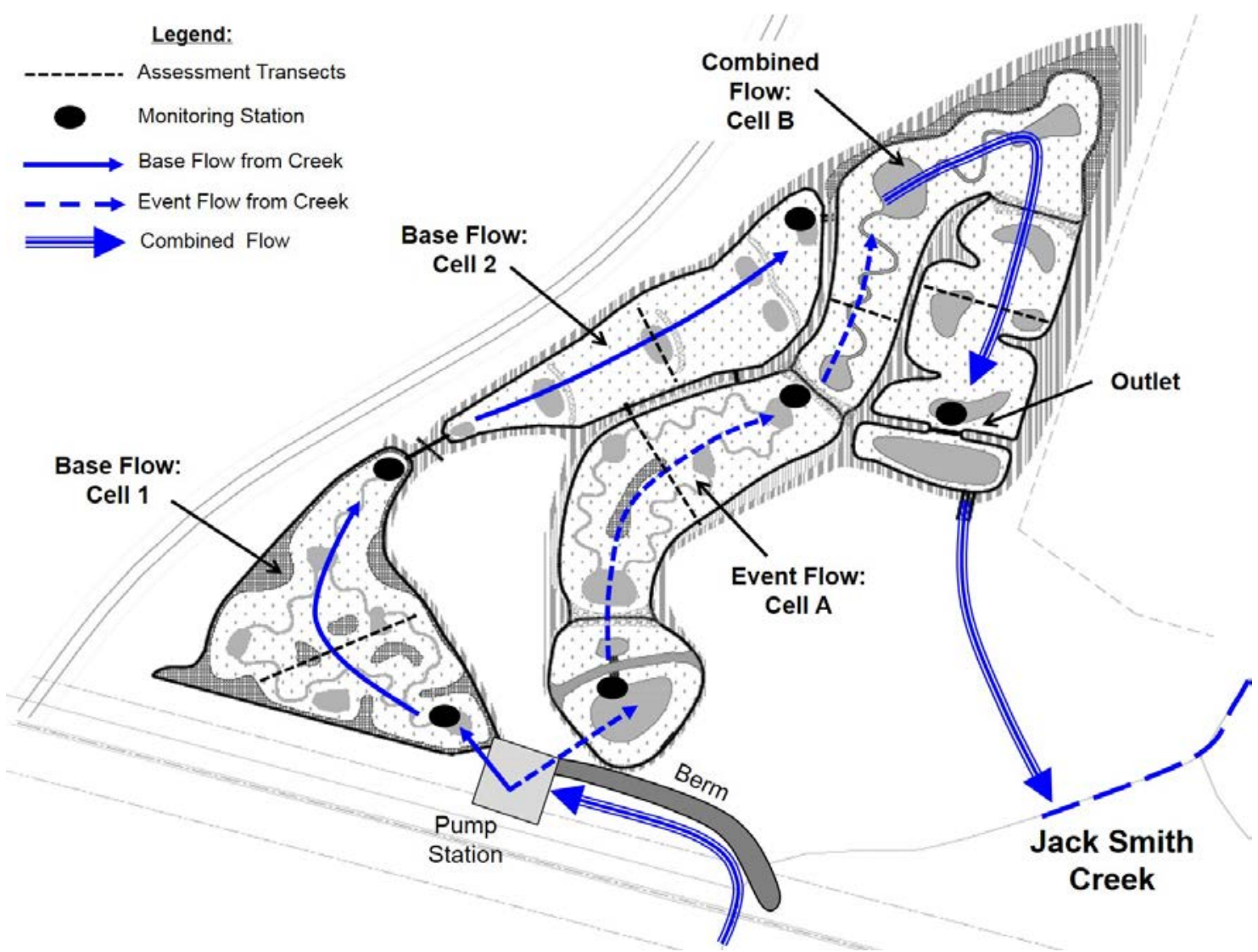

Figure 2: Schematic of Jack Smith Creek constructed stormwater wetland

The size and multi-cell design of the CSW produced a treatment train. The cells had a combined area of 6.78 ha and a total storage of $10,935 \mathrm{~m}^{3}$ (Table 1). The design incorporated varying bathymetry (Greenway et al., 2007; Hunt et al., 2007) with temporary inundation zones (only ponded during events), shallow water zones ( $0.1 \mathrm{~m}$ deep at normal pool), open water pools ( $>$ $0.45 \mathrm{~m}$ ), and transition zones between to diversify habitat. During the dormant season (January 2013), 2800 trees and shrubs were planted on the fringe of the CSW, and in April and May 2013, hydrologic zones were planted with 150,000 herbaceous emergent species plugs. Common species planted included Pontedaria cordata (pickerelweed), Peltandra virginica (arrow arum), 
Scirpus tabernaemontani (soft stem bulrush), Juncus effusus (common rush), Hibiscus

moscheutos (rose mallow), Lobelia cardinalis (cardinal flower), and Taxodium distichum (bald cypress).

Table 1: Descriptions of Jack Smith Creek CSW cells shown in Figure 2

\begin{tabular}{cccccc}
\hline Cell & $\begin{array}{c}\text { Area } \\
(\mathrm{ha})\end{array}$ & $\begin{array}{c}\text { Ponding } \\
\text { Depth }(\mathrm{cm})\end{array}$ & $\begin{array}{c}\text { Storage } \\
\left(\mathrm{m}^{3}\right)\end{array}$ & $\begin{array}{c}\text { Average } \\
\text { HRT }(\text { days })^{*}\end{array}$ & $\begin{array}{c}\text { Shortest Hydraulic } \\
\text { Distance }(\mathrm{km})\end{array}$ \\
\hline Cell 1 & 1.67 & 10 & 1670 & $0.2-0.4$ & 0.22 \\
Cell 2 & 1.15 & 10 & 1150 & $0.2-0.4$ & 0.25 \\
Cell A & 1.45 & 30 & 4350 & $0.4-0.7$ & 0.22 \\
Cell B & 2.51 & 15 & 3765 & $1.75-2.0$ & 0.32 \\
\hline Total & 6.78 & - & 10,935 & $2.0-3.0$ & $0.5-0.8$ \\
\hline
\end{tabular}

$*$ Hydraulic Retention Time $(\mathrm{HRT})=$ Volume of Cell $\div \mathrm{Q}$ where $\mathrm{Q}=\left(\right.$ flow $_{\text {in }}+$ flow $\left._{\text {out }}\right) \div 2$ (USEPA, 1988)

Monitoring stations for water quality and hydrology were installed at locations within the CSW that had flow control structures (Figure 2). Biodiversity of vegetation and soil carbon surveys were conducted along a series of five transects spatially distributed (Figure 2) to obtain a representative sample of the CSW and were generally arranged along a gradient from the inlet to outlet (Richardson and Vymazal, 2001; Moore and Hunt; 2012). These transects intersected the three distinct hydrologic zones (open water - OW, shallow water - SW, and temporary inundation - TI).

Sampling methods and statistical analyses for each of the services assessed are discussed in subsequent sections. All statistical analyses were performed using the statistical software, $R$, version 3.1.3 and complimentary user interface: $R$ Studio, version 0.99.441 (R Core Team 2015). A criterion of $95 \%$ confidence $(\alpha=0.05)$ was used to determine statistical significance. 


\section{Hydrologic Monitoring}

Hydrologic monitoring was conducted between June 2013 and October 2014. Flow was measured at the inlet of Cell 1 and Cell A and the outlet of succeeding cells (Figure 2). A large (4.87 m length by $1.83 \mathrm{~m}$ width) concrete, rectangular box weir facilitated conveyance, and installation of an ISCO 730 bubbler module (Teledyne ISCO, Lincoln, NE, USA) was used to measure flow from the forebay into Cell A (Table 2). Runtime (and therefore volume) from the base flow electric pump (Cell 1 inlet) was measured with a motor on/off logger (Onset Computer Corp., MA, USA, HOBO UX90-004). The outlets of Cells 1 and 2 were corrugated metal and plastic pipes, respectively, each with ISCO 750 area velocity flow modules. The outlets of Cells A and B were a rock broad-crested weir and a concrete labyrinth weir (Figure 3), respectively. ISCO 730 bubbler modules were used to measure stage at these locations. Flow was calculated using appropriate stage-discharge relationships for each location (Table 2), and all measurements were taken on a 2-minute interval. Four Davis tipping-bucket rain gauges (Davis Instrumental Corp., Hayward, CA, USA) coupled with HOBO event loggers (Model H07-00204) and one ISCO 674 tipping-bucket rain gauge were spatially distributed in the contributing watershed (Figure 1). The Thiessen polygon method was used to calculate the average watershed rainfall for each storm event (Haan et al., 1993). 


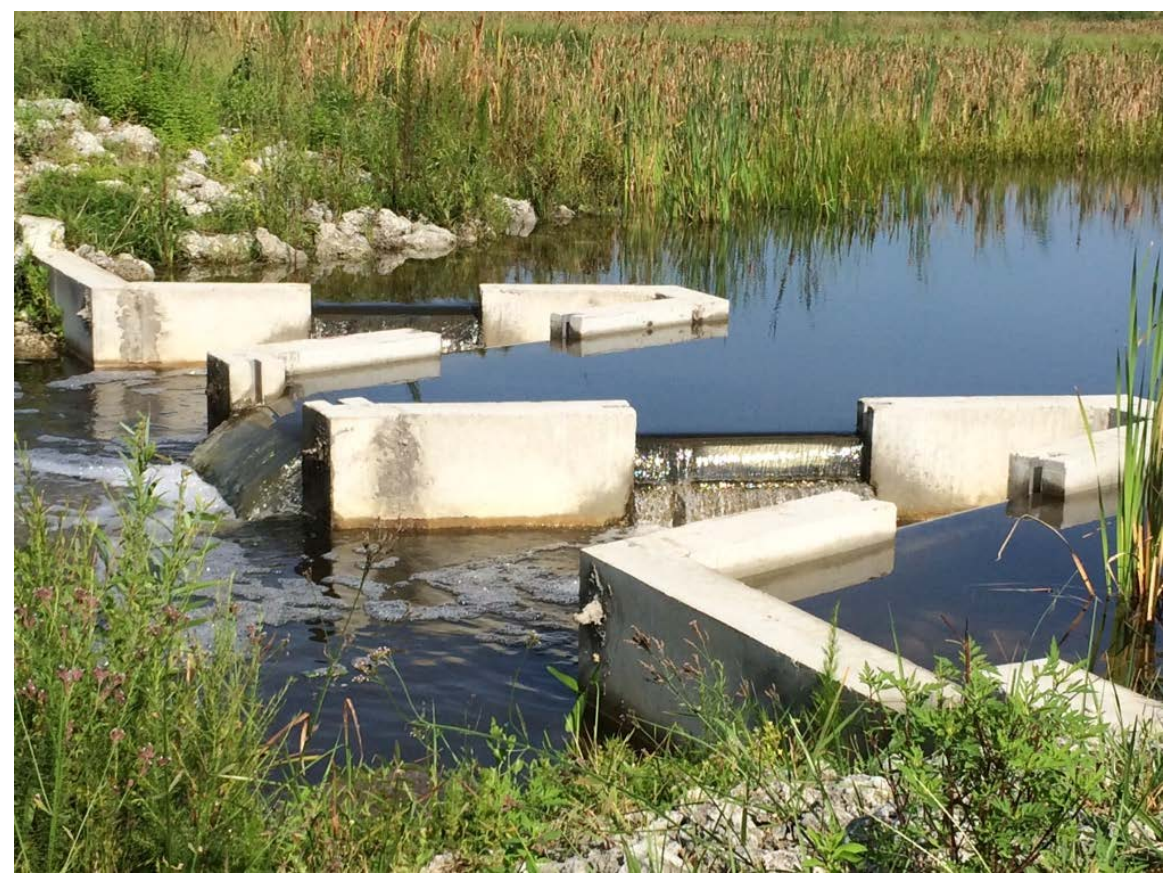

Figure 3: The labyrinth weir used as the flow control structure at the Cell B Outlet.

Table 2: Monitoring equipment used in study

\begin{tabular}{|c|c|c|c|c|}
\hline Location & Flow Control & $\begin{array}{c}\text { Hydrologic } \\
\text { Measurement }\end{array}$ & Discharge Relationship & $\begin{array}{c}\text { Water Quality } \\
\text { Sampling }\end{array}$ \\
\hline $\begin{array}{l}\text { Cell } 1 \\
\text { Inlet }\end{array}$ & $\begin{array}{l}\text { Electric Pump } \\
\quad(3785 \mathrm{lpm})\end{array}$ & $\begin{array}{l}\text { HOBO UX90-004 } \\
\text { Motor On/Off } \\
\text { Logger }\end{array}$ & $\mathrm{Q}=$ Constant & $\begin{array}{c}\text { Discrete } \\
\text { Biweekly }\end{array}$ \\
\hline $\begin{array}{l}\text { Cell } 1 \\
\text { Outlet }\end{array}$ & $\begin{array}{l}\text { Arched Corrugated } \\
\text { Metal Pipe } \\
\text { (1 x } 0.75 \text { m Dia. })\end{array}$ & \multirow{2}{*}{$\begin{array}{l}\text { ISCO } 750 \text { Area } \\
\text { Velocity Flow } \\
\text { Module } \\
\text { (measured stage } \\
\text { and velocity) }\end{array}$} & \multirow{2}{*}{$\begin{array}{c}\mathrm{Q}=\text { Velocity } * \text { Wetted Area } \\
\text { Wetted Area }=\mathrm{f}(\text { Stage }, \text { pipe } \\
\text { dimensions })\end{array}$} & $\begin{array}{l}\text { Grab Samples } \\
\text { via ISCO } \\
6712 \\
\text { Automated }\end{array}$ \\
\hline $\begin{array}{l}\text { Cell } 2 \\
\text { Outlet }\end{array}$ & $\begin{array}{l}2 \text { Corrugated Plastic } \\
\text { Pipes ( } 0.90 \text { Dia.) }\end{array}$ & & & Samplers \\
\hline $\begin{array}{l}\text { Cell A } \\
\text { Inlet }\end{array}$ & $\begin{array}{c}\text { Concrete Rectangular } \\
\text { Box Weir } \\
(4.87 \times 1.83 \mathrm{~m})\end{array}$ & \multirow{2}{*}{$\begin{array}{c}\text { ISCO } 730 \text { Bubbler } \\
\text { Modules } \\
(\mathrm{H}=\text { Stage })\end{array}$} & $\begin{array}{l}\text { Sharp-Crested Rectangular } \\
\text { Weir: } \\
\mathrm{Q}(\mathrm{L} / \mathrm{s})=1838(\mathrm{~L}-0.2 \mathrm{H}) \mathrm{H}^{1.5}\end{array}$ & \multirow{3}{*}{$\begin{array}{c}\text { Flow } \\
\text { Weighted } \\
\text { Samples via } \\
\text { ISCO 6712 } \\
\text { Automated } \\
\text { Samplers }\end{array}$} \\
\hline $\begin{array}{l}\text { Cell A } \\
\text { Outlet }\end{array}$ & $\begin{array}{l}\text { Rock Broad-Crested } \\
\text { Weir } \\
\text { (Length }=12.2 \mathrm{~m} \text { ) }\end{array}$ & & $\begin{array}{c}\text { Broad-Crested Weir: Q (cms) } \\
=0.18 \mathrm{LH}^{1.5}\end{array}$ & \\
\hline $\begin{array}{l}\text { Cell B } \\
\text { Outlet }\end{array}$ & $\begin{array}{l}\text { Labyrinth Weir } \\
\text { (Figure 3): }\end{array}$ & $\begin{array}{c}\text { ISCO } 730 \text { Bubbler } \\
\text { Modules } \\
(\mathrm{H}=\text { Stage })\end{array}$ & $\begin{array}{l}\text { Same as Cell A Inlet unless } \\
\mathrm{H}>30 \mathrm{~cm} \text {, then Q was } \\
\text { calculated via the Tullis et al. } \\
\text { Method (1995) }\end{array}$ & \\
\hline
\end{tabular}


Two flows were examined: base and storm. Since the base flow and storm event flow merged before reaching the outlet (Cell B outlet) of the CSW, the hydrology at the outlet mimicked that of a flashy stream (constant base flow and peaks of quick, or event, flow). These data were digitally filtered $(\alpha=0.95$, Passes $=3)$ with a Base Flow Separation tool (EcoHydRology package: Fuka et al., 2014) created by Nathan and McMahon (1990) to separate the two flow types. Individual storm flow event volumes were statistically compared to preceding monitoring stations (Cell A inlet and outlet, Figure 2). The base flow was analyzed on a monthly time step at the inlet and outlet of Cells 1 and 2, and the outlet of Cell B (Figure 2).

The storm event data (by events) and base flow (monthly) were analyzed independently. Each dataset was analyzed for normality using the Shapiro-Wilk test and Q-Q plots. Because data were normal (Shapiro Wilk, $p$-value $>0.05$ ), a paired Student's $t$-test was used to compare between monitoring stations. The one-way analysis of variance (ANOVA) and subsequent Tukey's Honest Significant Difference (HSD) test were used to determine the effect of seasonality $\left(1^{\text {st }}\right.$ growing, dormant, $2^{\text {nd }}$ growing seasons $)$.

\section{Water Quality Monitoring}

Water quality samples were collected at each flow monitoring point from June 2013 through October 2014 (Table 2). Monitored hydrographs enabled collection of flow-weighted samples and event mean concentrations (EMCs) for storm events. The constant base flow cells (Cells 1 and 2) were essentially grab sampled and retrieved every two weeks. Water quality samples at the Cell B Outlet were collected within 2 days of a large storm event (> $25 \mathrm{~mm})$ corresponding to the average HRT for Cell A and Cell B (Table 1). Therefore, due to sample timing, measured 
concentrations at Cell B Outlet were attributed to predominantly storm events (Cell A Inlet), not base flow, and were used in storm flow paired analyses. Cell B Outlet was not used in base flow water quality analyses due to the small number of samples retrieved comprising only baseflow.

Samples were collected using ISCO 6712 portable automated samplers (Table 2) and analyzed for Total Kjeldahl Nitrogen (TKN), Total Ammoniacal Nitrogen (TAN), Oxidized Nitrogen $\left(\mathrm{NO}_{2-3}\right)$, Total Phosphorus (TP), and Total Suspended Solids (TSS). Due to logistical reasons, Orthophosphate (Ortho-P) was not analyzed for every sampling event; however, it was analyzed for a few events in summer 2013 and a year later in summer 2014. Samples were retrieved from the CSW within 48-60 hours of the event's completion to allow for proper drawdown and capture of the majority of the hydrograph. The samples were put on ice (chilled to $<4^{\circ} \mathrm{C}$ ) and transported to the North Carolina State University Center for Applied Aquatic Ecology (CAAE) laboratory, approximately $180 \mathrm{~km}$ from the research site, for chemical analyses (Table 3).

Table 3: Laboratory analytical methods and reporting limits.

\begin{tabular}{|c|c|c|c|}
\hline Pollutant & Pollutant Name & Analytical Method & $\mathrm{RL}^{\mathrm{a}}$ \\
\hline $\mathrm{NO}_{2,3}$ & Nitrite + Nitrate Nitrogen & $\mathrm{SM} 4500 \mathrm{NO}^{\mathrm{b}} \mathrm{F}^{\mathrm{b}}$, EPA $353.2^{\mathrm{b}}$ & 0.0056 \\
\hline $\mathrm{TKN}$ & Total Kjeldahl Nitrogen & SM $4500 \mathrm{~N}$ org $\mathrm{D}^{\mathrm{b}}$, EPA 351.2 & 0.28 \\
\hline TAN & Total Ammoniacal Nitrogen & $\mathrm{SM} 4500 \mathrm{NH} 3 \mathrm{G}^{\mathrm{b}}, \mathrm{EPA} 350.1$ & 0.007 \\
\hline $\mathrm{ON}$ & Organic Nitrogen & $=\mathrm{TKN}-\mathrm{TAN}$ & - \\
\hline $\mathrm{TN}$ & Total Nitrogen & $=\mathrm{TKN}+\mathrm{NO}_{2,3}$ & - \\
\hline Ortho-P & Orthophosphate & SM 4500-P-F ${ }^{b}$, EPA 365.1 & 0.006 \\
\hline $\mathrm{TP}$ & Total Phosphorus & SM 4500-P-F ${ }^{b}$, EPA 365.1 & 0.01 \\
\hline TSS & Total Suspended Solids & SM $2540 \mathrm{D}^{\mathrm{b}}$ & 2.5 \\
\hline
\end{tabular}

${ }^{\mathrm{a}}$ Reporting Limits (mg/L)

${ }^{\mathrm{b}}$ APHA, 2012

The water quality analyses were adapted from Wadzuk et al. (2010) and are presented by base flow concentrations and storm EMCs in addition to mass loads. The event mass for each 
pollutant was calculated (Eq. 1) by multiplying volume of the event $\left(\mathrm{m}^{3}\right)$ by the EMC $(\mathrm{mg} / \mathrm{L})$ :

$$
\text { Mass }_{\text {event }}=E M C * V_{\text {event }}
$$

The base flow masses were calculated (Eq. 2) by multiplying the average monthly concentrations $\left(\bar{C}_{\text {Monthly }}\right.$ in $\left.\mathrm{mg} / \mathrm{L}\right)$ by the total monthly flow volumes, $V_{\text {Monthly }}$ (Richards, 1999).

$$
\text { Mass }_{\text {Monthly }}=\bar{C}_{\text {Monthly }} * V_{\text {Monthly }}
$$

Calculated event masses calculated were summed then normalized on an annual basis and by watershed area (ha) (Eq. 3):

$$
\text { Loading }(\mathrm{kg} / \mathrm{ha} / \text { year })=\frac{\sum \operatorname{Mass}_{\text {event }}(\mathrm{kg})}{\text { Watershed Area }(\mathrm{ha})} \frac{\text { Rainfall Monitored }}{\text { Annual Rainfall }(\text { year })}
$$

Baseflow annual loadings were calculated in the same manner as event annual loadings (Eq. 3); however, since baseflow is not directly event driven, the rainfall ratio was replaced with the ratio of one year: monitoring period length (365 days/515 days). While the bi-weekly design (baseflow) provided a relatively fine temporal sampling resolution, the authors acknowledge that averaging the monthly concentrations did introduce variability and thus, uncertainty to the projected monthly loads.

Exceedance probability was used to examine pollutant concentrations for each monitoring station (Strecker et al., 2001; Li and Davis, 2009; Wadzuk et al., 2010). The concentration data were checked for normality using the Shapiro-Wilk test and visually inspecting the boxplots and 
normal Q-Q plots and were found to have various distributions. To maintain consistency in analyses, a non-parametric Wilcoxon signed-ranked test was chosen to determine statistical significance of comparisons. The Kruskal-Wallis test and post hoc Dunn test with Bonferroni adjustment were used to determine the effect of seasonality, dormant versus $1^{\text {st }}$ and $2^{\text {nd }}$ growing seasons. Event and monthly base flow loadings were also checked for normality using the Shapiro-Wilk test and visual inspection normal Q-Q plots. These data fit a normal distribution with a square root transformation, enabling a paired Student's $t$-test to compare between monitoring stations. The one-way analysis of variance (ANOVA) and subsequent Tukey's Honest Significant Difference (HSD) test were used to determine the effect of seasonality.

\section{Vegetation Assessments}

Vegetation diversity was assessed within a $0.25-\mathrm{m}$ by $0.25-\mathrm{m}$ quadrant placed within representative vegetation communities along transects (Figure 2) covering each hydrologic zone (Moore and Hunt, 2012). The vegetation within each quadrant was identified and recorded. For each assessment, the vegetation records were pooled by hydrologic zone (i.e. summation of the 5 recordings for all 3 zones). Species richness (number of species observed) was determined for each zone along with diversity, which was quantified by the Shannon diversity index, $\mathrm{H}$

(Shannon and Weaver, 1949). Vegetation surveys were conducted six times, on average every 100 days. No observations were found in the OW zone, typical of CSWs in North Carolina since they are usually too deep to support vegetation and are not planted (Moore and Hunt, 2012).

The distribution of vegetation data (richness and diversity-Shannon's $\mathrm{H}$ ) did not follow any known distribution. To test for difference, spatially, between the SW and TI hydrologic zones, 
the non-parametric Wilcoxon signed-rank test was used. Temporal observations were compared to those found in Moore and Hunt (2012).

\section{Soil Carbon Assessments}

The soil organic C content of the CSW's sediments was measured four times during the monitoring period: May and November 2013 and June and October 2014. This established a C content baseline for the CSW, and enabled comparison from the first to second year. At each transect (Figure 2), one soil sample was obtained from each hydrologic zone: totaling fifteen samples per survey. At each sampling point, the upper $100 \mathrm{~mm}$ of the sediment profile was collected with a $50 \mathrm{~mm}$ diameter soil core. This sampling depth targeted the relatively shallow soil depth where changes in C content were expected to occur (Bruland and Richardson, 2006).

Bulk density measurements were conducted on all individual cores. The cores were oven-dried at $105^{\circ} \mathrm{C}$ for a $36-48$ hour period and weighed (Blake and Hartge, 1986). The five bulk density measurements of the same hydrologic zone were averaged. A subsample from each core was pooled by hydrologic zone, ground to less than $250 \mu \mathrm{m}$, and analyzed for \% C (g C per g soil). Percent $\mathrm{C}$ was measured at the NC State University Environmental and Agricultural Testing Services Laboratory in Raleigh, North Carolina, USA, through dry combustion at $550^{\circ} \mathrm{C}$ with a Perkin-Elmer $2400 \mathrm{CHN}$ Elemental Analyzer (Golubiewski, 2006). To assume the total C from these analyses was equal to organic $\mathrm{C}$ content, the inorganic $\mathrm{C}$ component, primarily in the form of calcium carbonates, must be negligible (Buell and Makewich, 2004). The soil at the CSW (Arapahoe fine sandy loam) is classified as being acidic and noncalcarous; therefore, inorganic $\mathrm{C}$ contribution by calcium carbonates was presumed negligible. The areal $\mathrm{C}$ density $\left(\mathrm{g} \mathrm{C} \mathrm{m}^{-2}\right)$ of 
each hydrologic zone (Eq. 4)4) was determined by multiplying the \% C soil content by the mean bulk density of the respective zone $\left(\overline{\rho_{b}}\right)$ and the depth of the soil sample $\left(d_{\text {core }}=0.1 \mathrm{~m}\right)$ (Pouyat et al., 2009; Bouchard et al., 2013).

$$
\text { Areal C Density }\left(g \mathrm{~g} \mathrm{~m}^{-2}\right)=\% C\left(\frac{g C}{g \text { Soil }}\right) * \overline{\rho_{b}}\left(\frac{g \text { soil }}{m^{3}}\right) * d_{\text {core }}(m)
$$

The nonparametric Kruskal-Wallis test was used to compare the areal C content among the hydrologic zones. Since the primary objective of measuring $\mathrm{C}$ content was to establish a C baseline for the site, linear regression analyses were not conducted to investigate accumulation. However, general observations regarding $\mathrm{C}$ accumulation between temporally corresponding samples (May 2013 vs. June 2014 and November 2013 vs. October 2014) were made.

\section{Results and Discussion}

\section{Hydrologic Services}

During the monitoring period, 44 rainfall events produced stage levels to engage the large storm event pump (Cell A Inlet). The total rainfall for the monitoring period (515 days) was $1695 \mathrm{~mm}$, which equated to a normalized annual rainfall of $1218 \mathrm{~mm}$. The 30-year average annual rainfall depth is $1387 \mathrm{~mm}$ for the area (Table 4; NCCO, 2015). 
Table 4: Rainfall summary and statistics for storm events only (inflow to Cell A) during the monitoring period

\begin{tabular}{lcc}
\hline Statistic & $\begin{array}{c}\text { All Monitoring Period } \\
\text { (515 Days) }\end{array}$ & $\begin{array}{c}\text { Events Sampled for } \\
\text { Water Quality }\end{array}$ \\
\hline Number of Events & 44 & $23^{\text {a }}$ \\
Mean Rainfall (mm) & 19 & 37 \\
Median Rainfall (mm) & 13 & 30 \\
Rainfall Depth Range (mm) & $4-93$ & $15-93$ \\
Total Rainfall for Monitoring Period (mm) & 1695 & 915 \\
Total Annual Rainfall (mm) & $1218^{\mathrm{b}}$ & - \\
\hline
\end{tabular}

${ }^{a}$ Comprised $81 \%$ of total volume entering Cell A during the monitoring period.

b 30 -year normal rainfall for the Craven County, NC Station was $1,387 \mathrm{~mm}$ and is located 9 kilometers from the research site (Data from NCCO, 2015).

Rainfall was the primary driver of higher stage in Jack Smith Creek and consequent storm inflows to Cell A. Influent to Cell 1 was mostly base flow but also included flow from storm events less than $25 \mathrm{~mm}$, on average. The electric pump had an average daily runtime of 9.3 hours/day for the monitoring period.

The total inflow volume measured for the monitoring period was approximately $2,300,000 \mathrm{~m}^{3}$ and was comprised of 75\% base flow (Cell 1 Inlet) and 25\% storm event flow (Cell A Inlet, Figure 4a). The total outflow was approximately $1,060,000 \mathrm{~m}^{3}$. For the monitoring period, the CSW reduced volumes significantly by $54 \%$. A significant volume reduction for storm event flow was not achieved until the latter part of the CSW (Cell B), but overall these event volumes were significantly reduced by $63 \%$ (Table 5). The same was true for the base flow cells, significant volume reductions did not occur until Cell 2 and Cell B (Table 5). Even though the flow regimes in Cell A and Cell 1 were very different (base flow vs. event flow), the volume reductions were very similar: $4 \%$ and $3 \%$, respectively. This is most likely due to the similar, short HRTs of both cells (Table 1). 


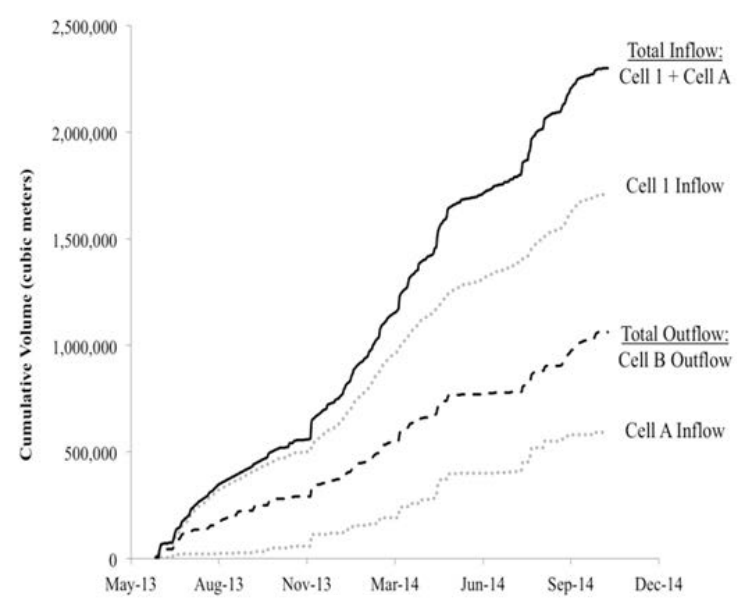

(a)

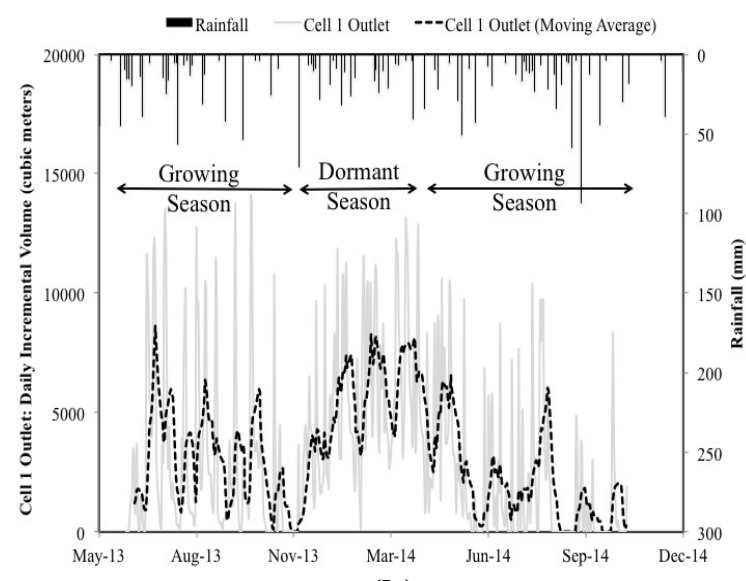

(b)

Figure 4: (a) Cumulative volume from individual inflows (Cell 1 and Cell A), total inflow (Cell $1+$ Cell A) and total outflow (Cell B outflow) (b) Cell 1 outlet daily incremental volume

Table 5: Volume reduction overall and for individual cells

\begin{tabular}{clcc}
\hline $\begin{array}{c}\text { Flow } \\
\text { Regime }\end{array}$ & \multicolumn{1}{c}{ Location } & $\begin{array}{c}\text { Volume } \\
\text { Reduction } \\
(\%)\end{array}$ & $\begin{array}{c}\text { Seasonality } \\
\text { Effect?** }\end{array}$ \\
\hline \multirow{2}{*}{ Event } & Cell A Inlet vs. Cell A Outlet & 4 & No \\
Flow & Cell A Outlet vs. Cell B Outlet (Events Only) & $61^{*}$ & No \\
& Total: Cell A Inlet vs. Cell B Outlet (Events Only) & $63^{*}$ & No \\
& Cell 1 Inlet vs. Cell 1 Outlet & 3 & Yes \\
Base & Cell 1 Outlet vs. Cell 2 Outlet & $37^{*}$ & Yes \\
Flow & Cell 2 Outlet vs. Cell B Outlet (Base Flow Only) & 22 & No \\
& Total: Cell 1 Inlet vs. Cell B Outlet (Base Flow Only) & $53^{*}$ & No \\
\hline Total & All Inflow vs. All Outflow & & \\
Flow & & $54^{*}$ & No \\
\hline
\end{tabular}

*Significant Volume Reduction (Student's paired $t$ test, $p$-value $<0.05$ )

**Significant Difference Between Growing \& Dormant Seasons (ANOVA \& Tukey's HSD, $p$-value $<0.05$ )

Significant differences were found among the seasons, but no significant difference existed between the $1^{\text {st }}$ and $2^{\text {nd }}$ growing seasons. This suggests that the change in weather-related (i.e. temperature and solar radiation) conditions, rather than wetland maturation, accounted for any differences. The incremental volume observed at Cell 1 outlet was greater in the dormant season 
as compared to the growing seasons (Figure 4b). Rainfall depth for each season was normalized by days in each season and was found to be $3.3,3.4$, and $3.2 \mathrm{~mm} /$ day for the $1^{\text {st }}$ growing, dormant, and $2^{\text {nd }}$ growing seasons, respectively, thus eliminating rainfall depth as a reason for seasonal differences.

Evapotranspiration (ET), although not measured directly, was determined for this CSW. The closest (9 kilometers) National Weather Service weather station provided reference crop ET (Penman-Monteith) monthly totals (NCCO, 2015). Monthly weighted crop coefficients for the CSW were determined from open water and cattail (Typha spp.) crop coefficients (Mao et al., 2002) and the visual observations of CSW surface area (SA) that was vegetated (Eq. 5).

$$
\text { Weighted } K_{c}=\left(\% S A_{\text {vegetated }}\right) K_{\text {cattails }}+\left(1-\% S A_{\text {vegetated }}\right) K_{\text {open water }}
$$

Actual ET was then determined for each month and summed for the monitoring period (Table 6) where ET losses attributed to approximately $13 \%$ of the of the total volume lost $\left(1,240,000 \mathrm{~m}^{3}\right)$. 
Table 6: Evapotranspiration (ET) loss estimates

\begin{tabular}{|c|c|c|c|c|c|c|c|}
\hline Month & $\begin{array}{c}\text { Mean } \\
\text { Monthly } \\
\text { Temperature } \\
\left({ }^{\circ} \mathrm{C}\right)\end{array}$ & $\begin{array}{l}\text { Ref ET } \\
(\mathrm{mm})^{\mathrm{a}}\end{array}$ & $K_{\text {cattails }}^{b}$ & $K_{\text {open water }}{ }^{b}$ & $\begin{array}{c}\text { Percentage of } \\
\text { Vegetated } \\
\text { SA }^{c}\end{array}$ & $\begin{array}{c}\text { Monthly } \\
\text { Weighted } \\
K\end{array}$ & $\begin{array}{l}\text { Actual } \\
\text { ET } \\
(\mathrm{mm})\end{array}$ \\
\hline June 2013 & 25.4 & 158.26 & 0.65 & 0.57 & $30 \%$ & 0.59 & 94.00 \\
\hline July 2013 & 27.0 & 156.76 & 0.56 & 0.53 & $40 \%$ & 0.54 & 84.96 \\
\hline Aug 2013 & 25.6 & 137.01 & 0.51 & 0.68 & $40 \%$ & 0.61 & 83.85 \\
\hline Sept 2013 & 22.6 & 115.52 & 0.61 & 0.74 & $50 \%$ & 0.68 & 77.98 \\
\hline Oct 2013 & 18.4 & 71.82 & 0.64 & 0.78 & $50 \%$ & 0.71 & 50.99 \\
\hline Nov 2013 & 11.9 & 60.74 & 0.73 & 0.77 & $40 \%$ & 0.75 & 45.79 \\
\hline $\begin{array}{c}\text { Dec } 2013 \\
\text { Jan } 2014\end{array}$ & $\begin{array}{c}10.8 \\
5.4\end{array}$ & $\begin{array}{l}46.46 \\
51.24\end{array}$ & $\begin{array}{l}0.87 \\
0.51\end{array}$ & $\begin{array}{l}0.85 \\
0.68\end{array}$ & $\begin{array}{l}40 \% \\
40 \%\end{array}$ & $\begin{array}{l}0.86 \\
0.61\end{array}$ & $\begin{array}{l}39.86 \\
31.36\end{array}$ \\
\hline Feb 2014 & 7.9 & 60.38 & 0.61 & 0.74 & $40 \%$ & 0.69 & 41.54 \\
\hline Mar 2014 & 10.0 & 94.71 & 0.64 & 0.78 & $50 \%$ & 0.71 & 67.24 \\
\hline April 2014 & 18.0 & 141.13 & 0.73 & 0.77 & $55 \%$ & 0.75 & 105.56 \\
\hline May 2014 & 22.8 & 166.17 & 0.87 & 0.85 & $60 \%$ & 0.86 & 143.24 \\
\hline June 2014 & 25.6 & 170.86 & 0.87 & 0.85 & $70 \%$ & 0.86 & 147.62 \\
\hline July 2014 & 26.5 & 164.24 & 0.78 & 0.76 & $75 \%$ & 0.78 & 127.29 \\
\hline Aug 2014 & 25.8 & 140.80 & 0.76 & 0.79 & $80 \%$ & 0.77 & 107.85 \\
\hline Sept 2014 & 24.1 & 108.56 & 0.86 & 0.70 & $80 \%$ & 0.83 & 89.89 \\
\hline Oct 2014 & 18.9 & 95.77 & 0.78 & 0.79 & $70 \%$ & 0.78 & 74.98 \\
\hline
\end{tabular}

${ }^{a}$ Reference ET (Penman-Monteith) from National Weather Service State $9 \mathrm{~km}$ from CSW (NCCO, 2015)

${ }^{\mathrm{b}}$ Crop Coefficients from Mao et al. (2002)

${ }^{\mathrm{c}}$ Percentage of CSW with Vegetative Cover. Determined by visual field observations

Seepage was the primary pathway for volume reduction (remaining $87 \%$ of volume lost). The hydraulic gradient $(0.15-1 \mathrm{~m} / \mathrm{m})$ between the CSW and surrounding areas (neighboring drainage canals and downstream surface water elevations) was conducive to infiltration losses. The in-situ underlying soils (Arapahoe fine sandy loam) consisted of a high capacity to transmit water with a saturated hydraulic conductivity of $5-15 \mathrm{~cm} /$ hour in the most limiting layer (NRCS, 2015). Unlike this study, most CSWs are relatively small in terms of size and HRTs and, with few exceptions, have not significantly reduced volume (Line et al., 2008; Wadzuk et al., 2010; Merriman and Hunt, 2014). However, it is not uncommon to see volume reductions of 24 $-76 \%$ due to ET and seepage in larger $(1.2-145 \mathrm{ha})$ wetlands, which were similar to the scale 
and HRTs herein (Rushton, 1996; Caldwell et al. 2007; Kaplan et al. 2011; Glenn et al., 2013).

Since this CSW was pumped and did not receive peak flow volumes directly from the contributing watershed, peak flow mitigation was not analyzed.

Cumulative inflow and outflow volumes were compared for the monitoring period, and no differences in the ratio between cumulative inflow and outflow were visually observed for the first 350 days (or the first two-thirds of the total volume entering the CSW): the trend was linear (Figure 5). This demonstrated that the CSW instantaneously provided hydrological services by regulating runoff volume reduction. The volume reduction seemed to slightly improve after 350 days, mostly likely due to the summer ET losses. The large surface area, large HRTs, underlying geology, and rapid establishment of and large surface area for vegetation enabled these water losses.

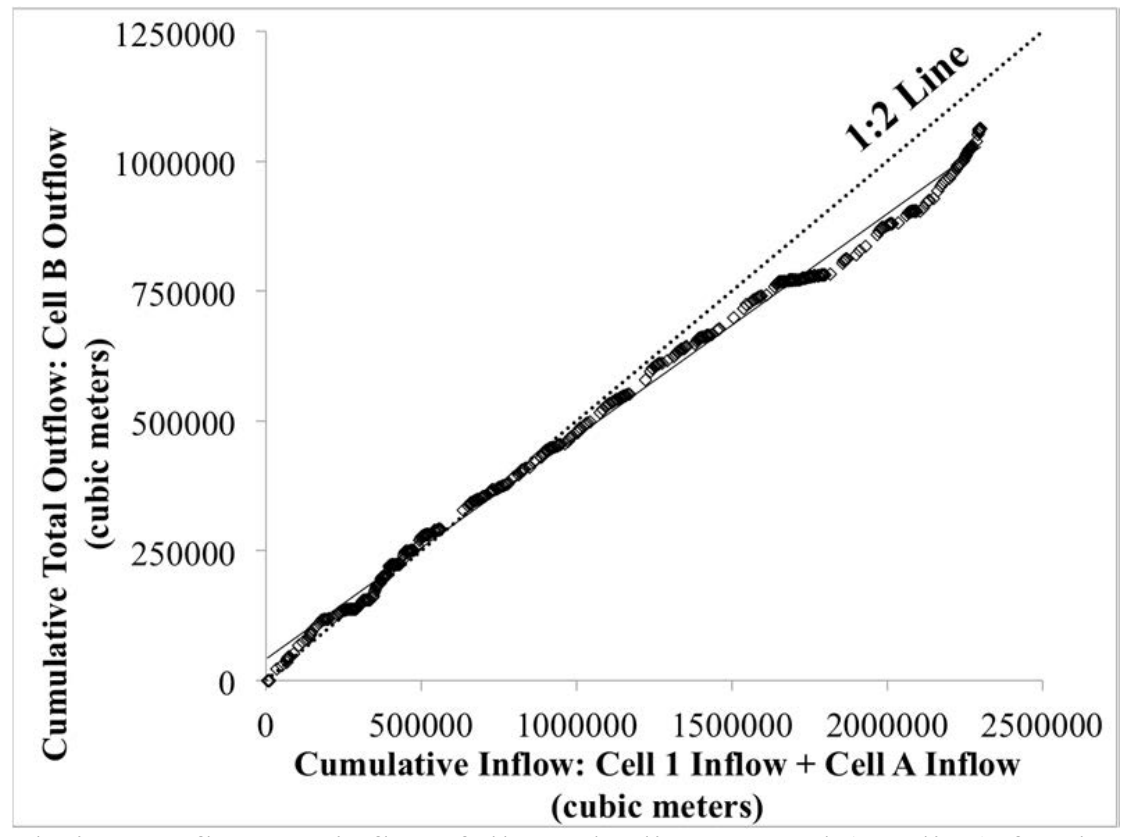

Figure 5: Cumulative outflow vs. inflow followed a linear trend (1:2 line) for the first two-thirds of flow entering the CSW (350 days), then volume reduction seemed to slightly improve for the rest of the monitoring period. 


\section{Water Quality Treatment Services}

Of the 44 hydrologic events monitored at the CSW, 23 were analyzed for water quality. These events accounted for $81 \%$ of the total event inflow (Cell A Inlet) and $54 \%$ of the total rainfall during the monitoring period (Table 4). Storm events were well distributed during the monitoring period and represented a wide range of depth and duration of rainfall. The EMCs (Figure 6) and mass loads (Figure 7) of all pollutants monitored were significantly reduced ( $p$ value $<0.05)$ from Cell A Inlet to Cell B Outlet; furthermore, EMCs of all analytes sampled were significantly reduced within the first cell (Cell A) with only $\mathrm{NO}_{2,3}$ and TP having reductions in Cell B (Table 7). Although there was no volume reduction in Cell A (Table 5), there was a significant reduction in mass loads for all pollutants in the cell. Cell B provided additional load reduction for all pollutants except TSS (Table 8). Seasonality only affected influent $\mathrm{ON}$ and TN, with loadings and EMCs being greater in the dormant season compared to the $1^{\text {st }}$ and $2^{\text {nd }}$ growing seasons $(p$-values $<0.05)$.

Twenty-seven base flow samples were collected during the monitoring period, which was, on average, every two weeks. All concentrations were reduced in Cell 1 except TAN (Table 7). Significant increases in ON, TP, and TSS were observed in Cell 2 (Table 7). Significant reductions in loads were observed in Cell 1 for all pollutants. Cell 2 experienced an increase in TSS loadings (Table 8). Inlet TN and TSS were greater in the dormant season relative to both growing seasons. The same was true for the Cell 1 Outlet for ON and TN. Total phosphorus and TSS loads were also higher in the dormant season at the outlet of Cell 2 (Table 8). 
Table 7: Median storm EMCs (mg/L) and base flow concentrations (mg/L)

\begin{tabular}{|c|c|c|c|c|c|c|}
\hline \multirow{3}{*}{ Pollutant } & \multicolumn{3}{|c|}{ Event Cells } & \multicolumn{3}{|c|}{ Base Flow Cells } \\
\hline & Cell A & Cell A & Cell B & Cell 1 & Cell 1 & Cell 2 \\
\hline & Inlet & Outlet & Outlet & Inlet & Outlet & Outlet \\
\hline TAN & 0.09 & $0.03 *$ & 0.03 & 0.07 & 0.06 & 0.06 \\
\hline $\mathrm{NO}_{2,3}-\mathrm{N}$ & 0.13 & $0.04 *$ & $0.02 *$ & 0.15 & $0.04 *$ & 0.03 \\
\hline $\mathrm{ON}$ & 1.14 & $0.48 *$ & 0.52 & 0.97 & $0.52 *$ & $0.81 *$ \\
\hline $\mathrm{TN}$ & 1.37 & $0.56^{*}$ & 0.64 & 1.38 & $0.68 *$ & 0.91 \\
\hline $\mathrm{TP}$ & 0.34 & $0.06^{*}$ & $0.04 *$ & 0.21 & $0.05 *$ & $0.07 *$ \\
\hline TSS & 54 & $3.6^{*}$ & 4.5 & 33 & $3.1 *$ & $8.6^{*}$ \\
\hline
\end{tabular}

*Significant difference in concentration compared preceding cell (Wilcoxon, $p$-value $<0.05$ )

Bold and italicized values indicate significant increases. 


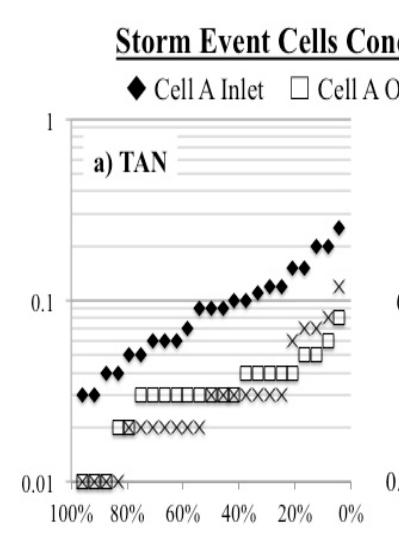

Concentrations (mg/L):
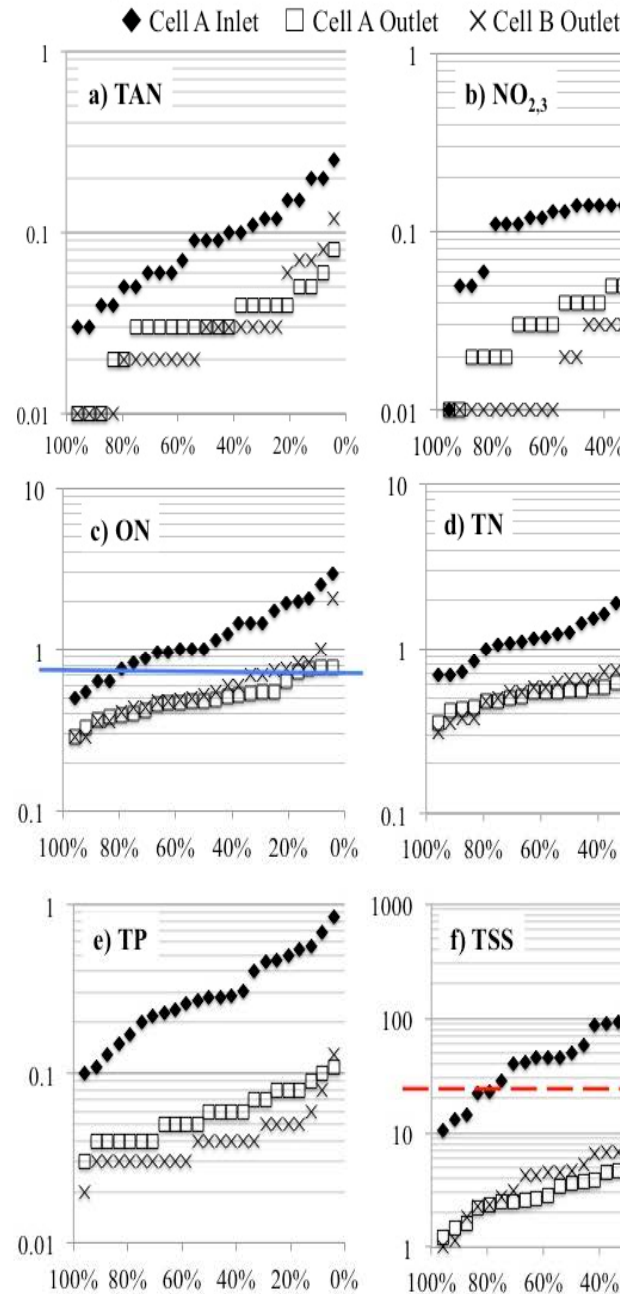

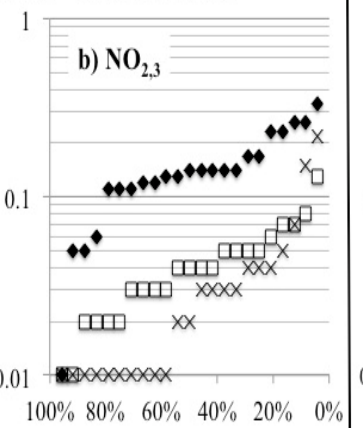

\section{0 d) TN}

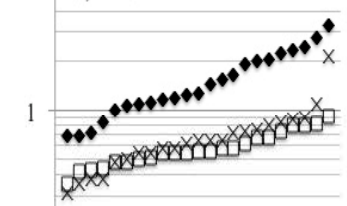

0.1
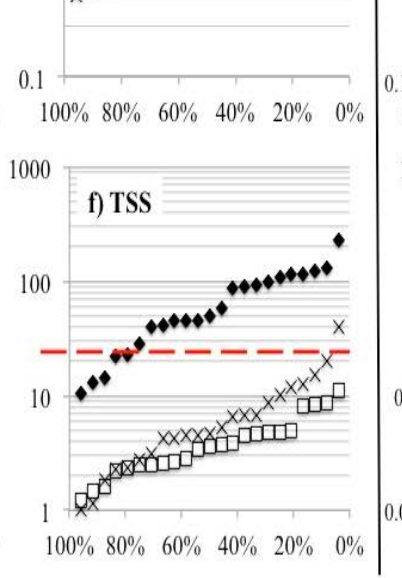

Base Flow Cells Concentrations (mg/L):

$\checkmark$ Cell 1 Inlet $\square$ Cell 1 Outlet $\times$ Cell 2 Outlet
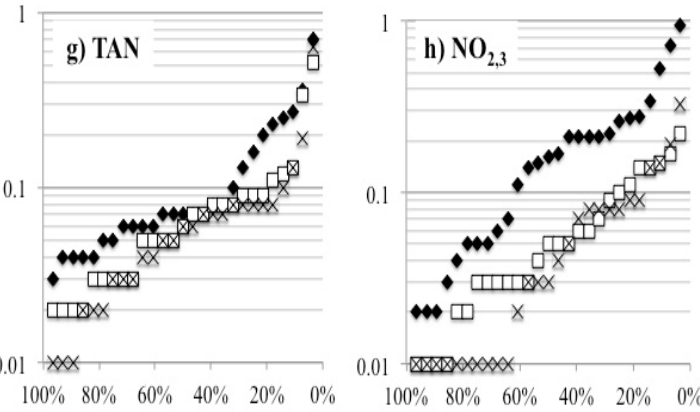

10
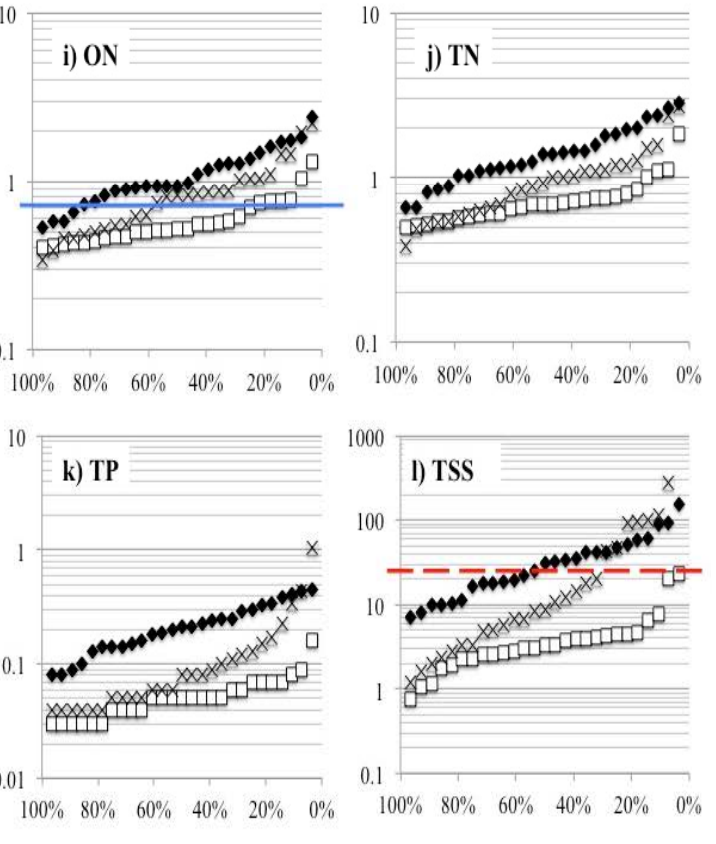

Exceedance Probability (\%)

Figure 6: Concentrations for storm event cells (left) and base flow cells (right) for (a,g) TAN $(\mathrm{b}, \mathrm{h}) \mathrm{NO}_{2,3}(\mathrm{c}, \mathrm{i}) \mathrm{ON}(\mathrm{d}, \mathrm{j}) \mathrm{TN}(\mathrm{e}, \mathrm{k}) \mathrm{TP}$ and $(\mathrm{f}, \mathrm{l}) \mathrm{TSS}$. Dashed red lines: TSS effluent target (Barrett et al., 2004). Blue solid line: typical ON exports of stormwater wetlands in NC (Moore et al., 2011). 
Table 8: Normalized annual loads $(\mathrm{kg} / \mathrm{ha} / \mathrm{yr})$ of pollutants for event and base flow

\begin{tabular}{|c|c|c|c|c|c|c|}
\hline \multirow{3}{*}{ Pollutant } & \multicolumn{3}{|c|}{ Events } & \multicolumn{3}{|c|}{ Base Flow } \\
\hline & Cell A & Cell A & Cell B & Cell 1 & Cell 1 & Cell 2 \\
\hline & Inlet & Outlet & Outlet & Inlet & Outlet & Outlet \\
\hline TAN & 0.10 & $0.04^{*}$ & $0.01 *$ & 0.18 & $0.12 *$ & 0.07 \\
\hline $\mathrm{NO}_{2,3}-\mathrm{N}$ & 0.18 & $0.05 *$ & $0.02 *$ & 0.39 & $0.12 *$ & 0.09 \\
\hline ON & 1.27 & $0.59 *$ & $0.24^{*}$ & 1.93 & $0.94^{*}$ & 0.88 \\
\hline $\mathrm{TN}$ & 1.55 & $0.68 *$ & $0.26^{*}$ & 2.50 & $1.47^{*}$ & 1.04 \\
\hline $\mathrm{TP}$ & 0.34 & $0.07 *$ & $0.02 *$ & 0.39 & $0.08 *$ & 0.16 \\
\hline TSS & 64 & $5^{*}$ & 3 & 66 & $7 *$ & $52 *$ \\
\hline
\end{tabular}

*Significant difference in load compared preceding cell (Student's $t$ test, $p$-value $<0.05$ )

Bold and italicized indicates significant difference between growing and dormant seasons (Tukey's HSD, p-value < 0.05)

Storm Events: Cumulative Loads $(\mathrm{kg})$ :

- Cell A Inlet $\square$ Cell A Outlet $\times$ Cell B Outlet

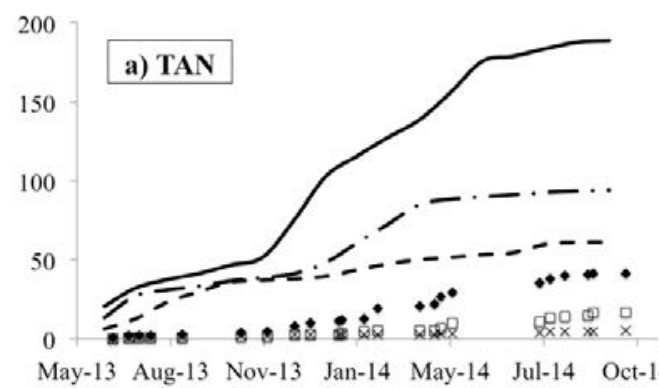
2000

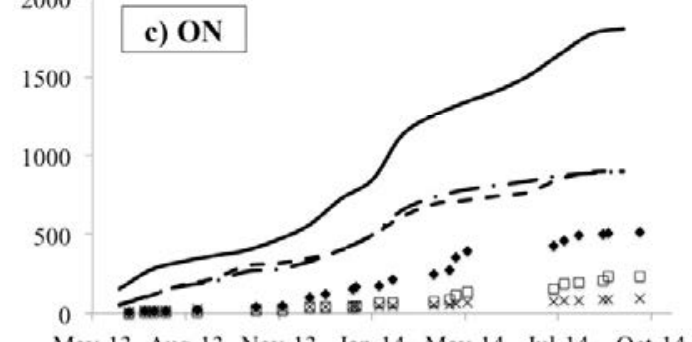

May-13 Aug-13 Nov-13 Jan-14 May-14 Jul-14 Oct-14

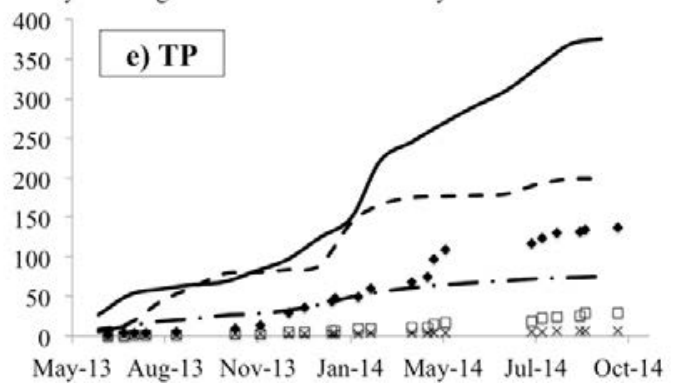

Base Flow: Cumulative Loads (kg):

Cell 1 Inlet Cell 1 Outlet Cell 2 Outlet

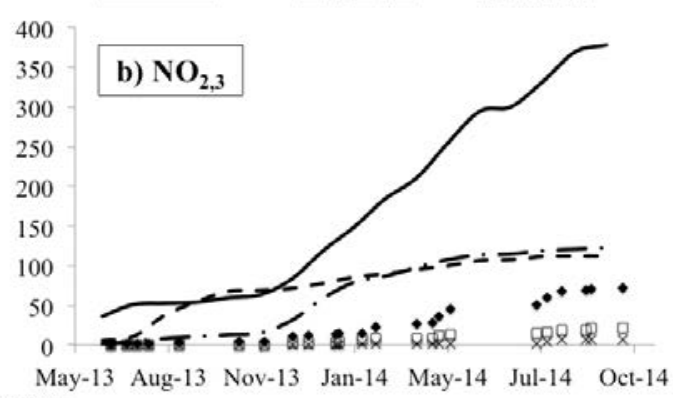
2500

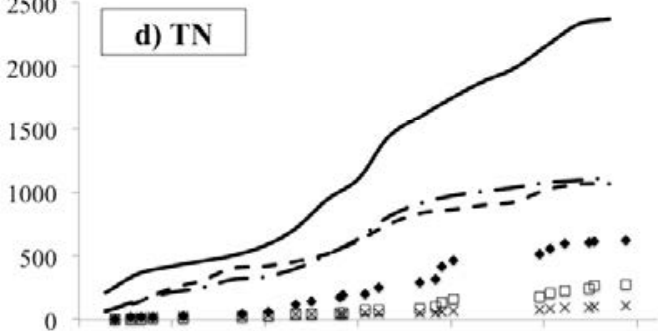

May-13 Aug-13 Nov-13 Jan-14 May-14 Jul-14 Oct-14

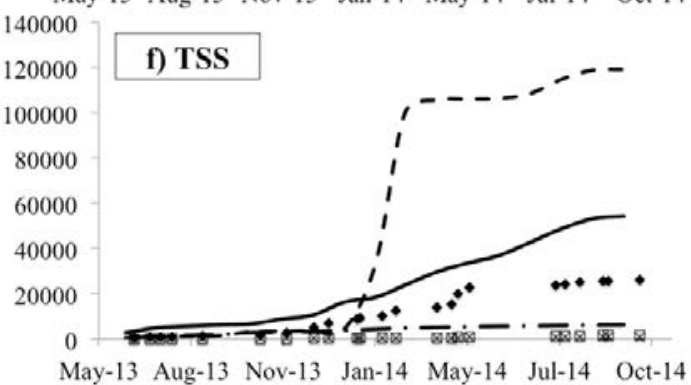

Figure 7: Cumulative loads for base flow and storm events: (a) TAN, (b) $\mathrm{NO}_{2,3}$, (c) $\mathrm{ON}$, (d) TN, (e) TP, and (f) TSS 
Overall, the CSW was effective in removing pollutants for both flow scenarios. All mass loadings (inlet and outlet) for base flow were significantly greater than those observed for events (Wilcoxon rank-sum, $p$-value $>0.05$ ); base flow volume accounted for $75 \%$ of the total flow entering and exiting the CSW. Overall the base flow concentrations were greater (Cell 1 and 2) compared to the event flow EMCs (Cells A and B) (Figure 6). Greenway (2004) summarized that interactions with sediment, microbes, and vegetation promote pollutant removal in CSWs. The average antecedent dry period (ADP) between storm events was 12 days, allowing water levels in Cell A and B to recede and extend the HRT to promote these interactions. In comparison, base flow cells of the CSW had a constant daily flow with negligible ADP forming a "flow-through" wetland scenario with less contact time (HRT) with the sediment-water interface.

The CSW reduced all nitrogen forms (Figure 6). Total ammoniacal nitrogen for event (Cell B Outlet) and base flow (Cell 2 Outlet) were relatively low, 0.03 and $0.06 \mathrm{mg} / \mathrm{L}$, respectively, and $\mathrm{NO}_{2,3}$ was discharged at similar concentrations ( 0.02 and 0.03 , respectively). Constructed stormwater wetlands in North Carolina have an ON background concentration of $0.7-0.8 \mathrm{mg} / \mathrm{L}$ (Moore et al., 2011); Cell 2 Outlet concentrations were slightly higher than this threshold (0.81 $\mathrm{mg} / \mathrm{L})$, but Cell B outlet EMCs were less than this threshold $(0.64 \mathrm{mg} / \mathrm{L})$. The significant increase in ON concentrations at the Cell 2 outlet (Table 7) was suspected due to $80 \%$ of this cell being vegetated by the end of the $1^{\text {st }}$ growing season, and the senescence of this vegetation probably reintroduced nutrients into the water column during the dormant season (Table 8; Kadlec and Wallace, 2008; Reddy and DeLaune, 2008).

The CSW sequestered approximately $0.55 \mathrm{~kg} / \mathrm{ha} / \mathrm{yr}$ of TP for the monitoring period (Table 7). 
Establishment of wetland hydrology at this site could lead to the release of iron-bound phosphorus from in-situ soils, due to the reduction of ferric to ferrous iron under anoxic conditions (Reddy et al., 1999; Hutchison and Hesterberg, 2004; Ardon et al., 2010). Orthophosphate was sampled twice in the $1^{\text {st }}$ growing season and three times in the $2^{\text {nd }}$ growing season (Table 9). The influent EMCs (event) and concentrations (base flow) were very low relative to other CSW studies (Birch et al., 2004; Line et al., 2008; Wadzuk et al. 2010), and reductions were observed as the flow traveled from cell to cell for each flow scenario.

Table 9: Orthophosphate (Ortho-P) observations in the $1^{\text {st }}$ and $2^{\text {nd }}$ growing seasons

\begin{tabular}{cccccccc}
\hline & \multicolumn{3}{c}{ Event EMC (mg/L) } & \multicolumn{3}{c}{ Base Flow Concentrations (mg/L) } \\
\hline \multirow{2}{*}{ Date } & $\begin{array}{c}\text { Cell A } \\
\text { Inlet }\end{array}$ & $\begin{array}{c}\text { Cell A } \\
\text { Outlet }\end{array}$ & $\begin{array}{c}\text { Cell B } \\
\text { Outlet }\end{array}$ & $\begin{array}{c}\text { Cell 1 } \\
\text { Inlet }\end{array}$ & $\begin{array}{c}\text { Cell 1 } \\
\text { Outlet }\end{array}$ & $\begin{array}{c}\text { Cell 2 } \\
\text { Outlet }\end{array}$ & $\begin{array}{c}\text { Cell B } \\
\text { Outlet }\end{array}$ \\
\hline 6/10/13 & 0.03 & 0.02 & 0.02 & 0.03 & 0.01 & 0.01 & 0.02 \\
$6 / 12 / 13$ & & & & & 0.03 & 0.02 & 0.02 \\
$7 / 7 / 14$ & & & & 0.07 & 0.02 & 0.01 & 0.01 \\
$7 / 27 / 14$ & 0.05 & 0.01 & 0.01 & 0.04 & 0.01 & 0.01 & 0.01 \\
$8 / 5 / 14$ & 0.04 & 0.02 & 0.01 & 0.06 & 0.03 & 0.01 & 0.01 \\
\hline
\end{tabular}

A significant increase in TP was observed at the Cell 2 outlet, similar to ON; however, this increase was most likely due to the large spike in TSS (and particle-bound phosphorus) in March 2014 rather than vegetation senescence (Table 8). The jump in TSS was due to scouring and accumulation of sediment at the sampling location of Cell 2's outlet. The sediment was thereafter removed and continuously checked until monitoring completion. Total suspended solids measured at the outlets of Cell 2 and B were 8.6 and $4.5 \mathrm{mg} / \mathrm{L}$, respectively, which was well below Barrett et al.'s (2004) TSS threshold of $25 \mathrm{mg} / \mathrm{L}$ for SCMs (Figure 6).

Water quality improvement in this CSW was likely achieved through a number of pollutant removal mechanisms: sedimentation, filtration, chemical sorption, microbial transformations, 
and assimilation by biota and aquatic plants (Greenway, 2004; Kadlec and Wallace, 2008). Hydraulic retention time, and proxies like flow rates through and contact time with microbial communities in the soil-water interface and biofilms, is critical to ensuring detention and cycling of nutrients (Wetzel, 2001). Two distinct flow scenarios (event, base) provided different ADPs and HRTs. The water quality treatment provided by Cells 1 and A allowed comparison of the two flow regimes, due to their similar areas and hydraulic distance (Table 1). Discharge concentrations were very similar, except TAN and TN were less at the Cell A Outlet compared to Cell 1 Outlet (Wilcoxon rank-sum $p<0.05$; Table 7). Overall, both cells performed well despite their differences in hydrology.

Although no statistical difference was found in treatment between the $1^{\text {st }}$ and $2^{\text {nd }}$ growing season, cumulative loadings were also visually investigated to evaluate ripening of the CSW. Cells that received base flow had no visual temporal trend. The performance was highly varied, most likely due to the range influent concentrations (Figure 6). For storm event Cells A and B, no ripening period was observed for $\mathrm{NO}_{2,3}$ and TSS; treatment was immediate and remained relatively constant (linear) for the monitoring period. For Cell A, mass removals for TAN, ON, TN, and TP had a slight ripening period of approximately 100 days (end of first growing season), but were overall relatively consistent (linear) (Figure 8). A more defined ripening period was observed for Cell B, where treatment improved after the first 300 days (peak of $2^{\text {nd }}$ growing season) of the monitoring period for TAN, ON, TN, and TP. The ripening of Cell A's water quality treatment is consistent with vegetation establishment during the first growing season, which provided relatively high pollutant removal of TAN, ON, TN, and TP. After initial establishment of wetland plant biomass, pollutant removal rates typically decrease and remain constant (Kadlec 
and Wallace, 2008). Because Cell A was less efficient after plant establishment (100 days), pollutant removal provided by Cell B commensurately increased in the latter stages of the study (300 days).

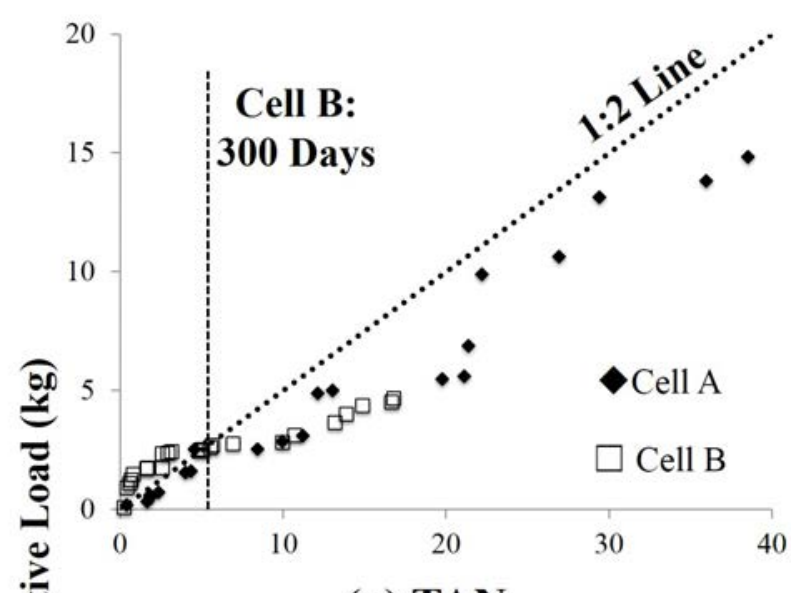

(a) TAN

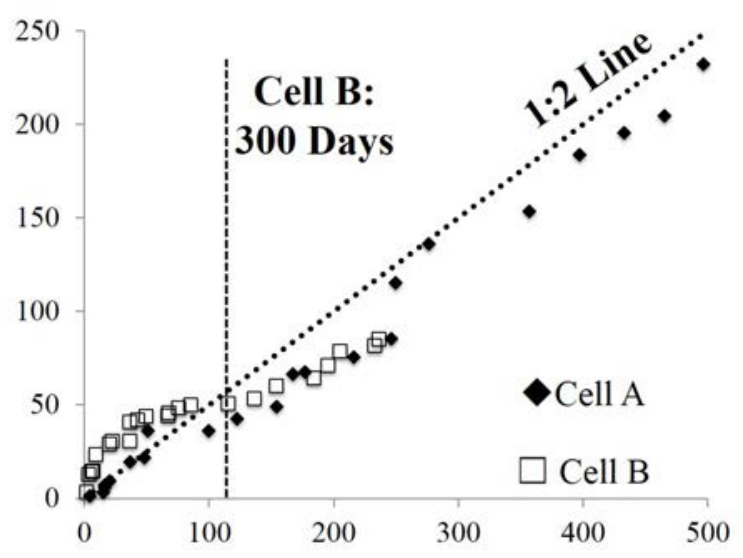

(b) $\mathrm{ON}$

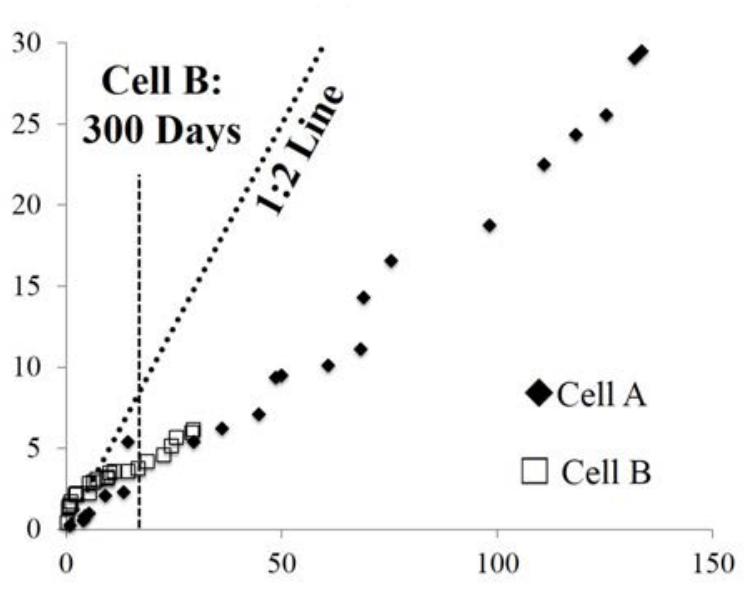

(d) TP

\section{Cell's Influent Cumulative Load (kg)}

Figure 8: Cumulative mass loadings (kg) for (a) TAN, (b) ON, (c) TN, and (d) TP for Cells A and $\mathrm{B}$ during the 515 days post construction.

Water level maintenance (due to adjustable outlet structures) and varying bathymetry were key in establishing aerobic and anaerobic zones to support microbial process key to water quality 
treatment (e.g. denitrification) and are highly recommended for all CSW designs (Greenway, 2004; Greenway et al., 2007).

Vegetation Biodiversity Services

Visual observations of the site revealed very little plant mortality after initial planting and rapid vegetation establishment (Figure 9). After the first observation, immediately post-planting in May 2013, Shannon's H remained relatively consistent (some fluctuations due to season) through the first two growing seasons with a median $=0.9$ for both the SW and TI zones (Table 10). The same was observed for species richness, with median values of 4.5 and 5.0 for the SW and TI zones, respectively (Table 10). There was no significant difference, spatially, between the SW and TI zones with respect to diversity (Wilcoxon signed-rank, $p=0.40$ ) and richness (Wilcoxon signed-rank, $p=0.41$ ). Species found in the SW and TI zones were those planted and mentioned previously with the exception of Typha spp. (Cattails). Cattails were not planted at the CSW but were observed in both the SW and TI zones during the latter part of the sampling period. Maintenance efforts have been in place since to remove and prevent Cattails from becoming a monoculture. 


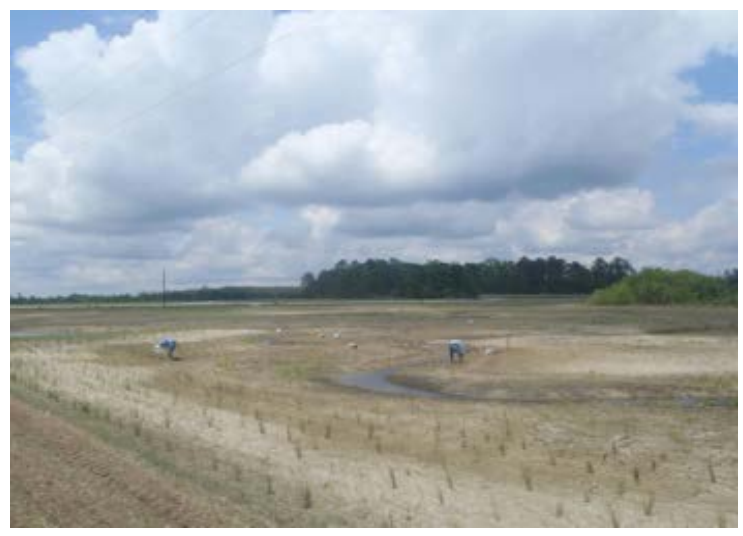

(a)

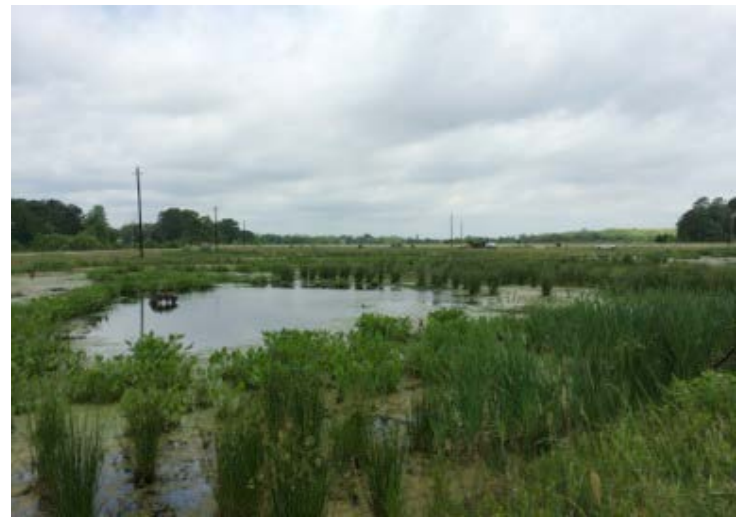

(c)

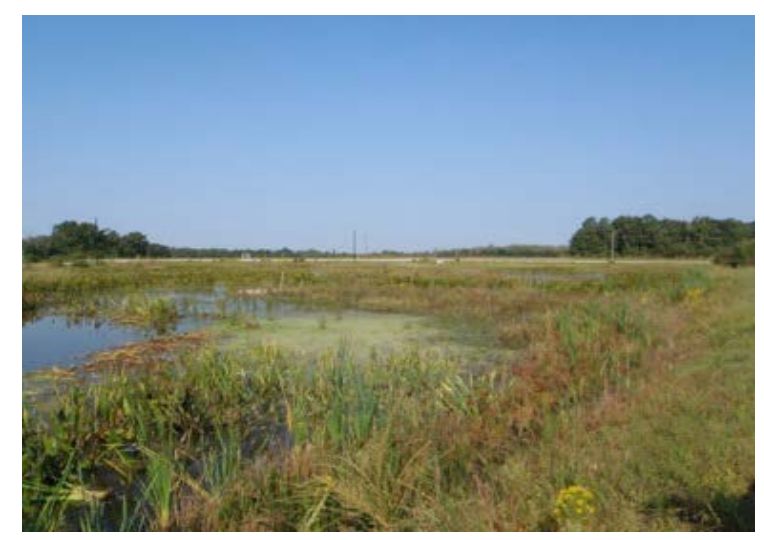

(b)

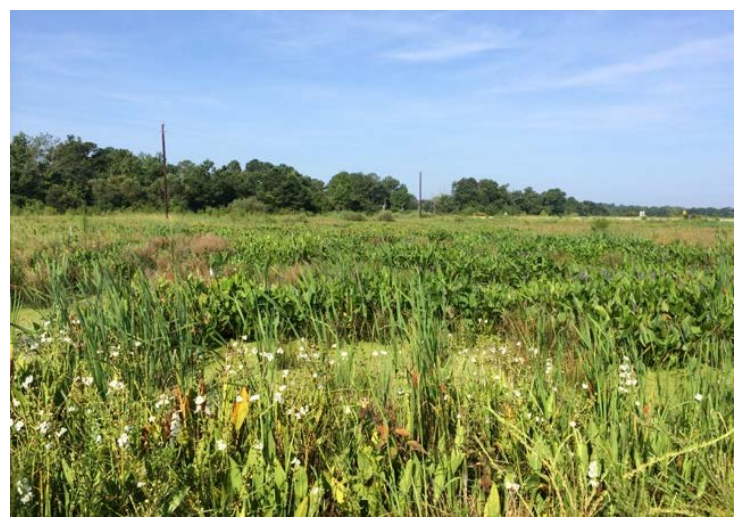

(d)

Figure 9: Vegetation development in Cell 1 of the CSW: (a) May 2013: planting, (b) October 2013: end of $1^{\text {st }}$ growing season, (c) May 2014: $2^{\text {nd }}$ growing season, (d) August 2014: peak of $2^{\text {nd }}$ growing season

Moore and Hunt (2012) surveyed 20 CSWs (median age $=5$ years) during the peak growing season months in North Carolina. When comparing the median values from this study to theirs, the values observed herein are less since this CSW was newly planted. However, when the maximum values of each metric are compared, the observations between the two studies were very similar - especially Shannon's H (Table 10). The maximum values for both zones were observed during the $2^{\text {nd }}$ growing season. This CSW began to provide a biodiverse vegetative community, comparable to other CSWs in North Carolina, by its $2^{\text {nd }}$ growing season. In addition to biodiversity contributions, microbiota and vegetation utilize plant-derived organic matter to 
drive pollutant removal processes such as denitrification (Reddy and DeLaune, 2008). High rates of productivity coupled with anaerobic environments can also create ideal conditions for C sequestration (Anderson and Mitsch, 2006; Euliss et al., 2006; Moore and Hunt, 2012).

Table 10: Vegetation richness and Shannon's diversity index $(\mathrm{H})$ observations during the first two growing seasons for the open water $(\mathrm{OW})$, shallow water (SW), and temporary inundation (TI) hydrologic zones

\begin{tabular}{|c|c|c|c|c|c|c|}
\hline & \multicolumn{3}{|c|}{ Shannon Diversity, H } & \multicolumn{3}{|c|}{ Richness } \\
\hline Date of Survey & OW & SW & TI & OW & SW & TI \\
\hline May 2013 & 0 & 0.0 & 0.6 & 0 & 0 & 5 \\
\hline October 2013 & 0 & 1.1 & 1.2 & 0 & 5 & 5 \\
\hline December 2013 & 0 & 0.9 & 0.9 & 0 & 4 & 4 \\
\hline March 2014 & 0 & 1.2 & 1.0 & 0 & 6 & 7 \\
\hline June 2014 & 0 & 0.9 & 1.4 & 0 & 6 & 6 \\
\hline October 2014 & 0 & 0.8 & 0.9 & 0 & 4 & 5 \\
\hline $\begin{array}{l}\text { Median Values from } \\
\text { Moore and Hunt, } 2012\end{array}$ & 0.07 & 1.3 & 1.4 & 1.0 & 7 & 9 \\
\hline
\end{tabular}

Maximum values are bolded.

Several design characteristics led to the rapid establishment of vegetation at this site. In addition to incorporating the three hydrologic zones discussed previously, the original topsoil was saved during construction and incorporated in the top $10 \mathrm{~cm}$ of the new topography, providing an organic matter source for vegetation (Hunt et al., 2007). During and after planting (April and May 2013), the water levels in the CSW were regulated to vary between $0-15 \mathrm{~cm}$ to allow vegetation establishment before the project went online (June 2013), and flashy fluctuations in water levels $(0-30 \mathrm{~cm})$ started. There was no difference observed in vegetation establishment in "flow-through", low fluctuation cells (1 and 2) and detention-designed, $30 \mathrm{~cm}$ fluctuation, cells (A and B). This demonstrated that differences in HRT and water levels did not have an effect on survivability, and vegetation can thrive in flashy systems with large fluctuations in water levels 
$(0-30 \mathrm{~cm})$ if allowed time (approximately 60 days) to establish.

The overall establishment of vegetation (approximately $80 \%$ vegetative coverage) was complete by the end of the $1^{\text {st }}$ growing season, approximately 165 days. This CSW provided a biodiverse vegetative community by the peak of its $2^{\text {nd }}$ growing season (400 days), comparable to other CSWs in North Carolina (Moore and Hunt, 2012). Additionally, this CSW seemed to provide both water quantity and quality regulating services even while the water level depth (and thus treatment capacity) was controlled to allow plant establishment.

\section{Carbon Sequestration Services}

No significant difference was found in areal C content among the hydrologic zones (KruskalWallis, $p$-value $=0.29$ ). The bulk density in each zone remained relatively constant indicating soil heterogeneity was kept to a minimum (Table 11). Overall, the median $\% \mathrm{C}$ observed in the SW zone $(1.1 \%)$ was larger than that observed in the OW and TI zones $(0.8 \%)$. The TI zone had the lowest areal C density $\left(971 \mathrm{~g} \mathrm{C} \mathrm{m}^{-2}\right)$, followed by the OW and SW zones with 1090 and 1361 $\mathrm{g} \mathrm{C} \mathrm{m}^{-2}$, respectively. Using the values reported by Moore and Hunt (2012) as a target hereafter, the $\%$ C content of the Jack Smith Creek CSW vegetated zones (TI and SW) are noticeably lower, which was expected since this CSW is in its infancy, and C accumulation was expected to be minimal. However, in the second year, areal C density observations for the OW and SW zones were more similar to the targets than anticipated (Table 11); the OW and SW areal C densities achieved and exceeded areal $\mathrm{C}$ density targets just 1 year after construction. Although areal $\mathrm{C}$ densities for TI did increase from during the first year, they are still well below the target of $2219 \mathrm{~g} \mathrm{C} \mathrm{m}^{-2}$ (Table 11). However, any assessment of $\mathrm{C}$ accumulation during this study 
should be tempered the relatively small sample size and soil heterogeneity in the CSW.

Table 11: Percent $C$, soil dry bulk density, and soil areal $\mathrm{C}$ density measurements during the first two years after construction

\begin{tabular}{|c|c|c|c|c|c|c|c|c|c|}
\hline \multirow[b]{2}{*}{ Date of Survey } & \multicolumn{3}{|c|}{ \% C (soil) } & \multicolumn{3}{|c|}{$\begin{array}{l}\text { Bulk Density } \\
\quad\left(\mathrm{g} / \mathrm{cm}^{3}\right)\end{array}$} & \multicolumn{3}{|c|}{$\begin{array}{l}\text { Areal C Density } \\
\qquad\left(\mathrm{g} \mathrm{C} \mathrm{m}^{-2}\right)\end{array}$} \\
\hline & OW & SW & TI & OW & SW & TI & OW & SW & TI \\
\hline May 2013 & 0.6 & 0.9 & 0.6 & 1.74 & 1.25 & 1.30 & 972 & 1164 & 808 \\
\hline November 2013 & 0.7 & 0.7 & 0.7 & 1.25 & 1.32 & 1.32 & 874 & 908 & 911 \\
\hline June 2014 & 1.1 & 1.3 & 0.8 & 1.18 & 1.27 & 1.28 & 1239 & 1683 & 1061 \\
\hline October 2014 & 0.9 & 1.3 & 0.8 & 1.33 & 1.20 & 1.26 & 1208 & 1558 & 1031 \\
\hline Median & 0.8 & 1.1 & 0.8 & 1.29 & 1.26 & 1.29 & 1090 & 1361 & 971 \\
\hline $\begin{array}{c}\text { Mean Values: } \\
\text { Moore and Hunt } 2012\end{array}$ & 1.4 & 2.0 & 2.4 & - & - & - & 1043 & 1436 & 2219 \\
\hline
\end{tabular}

Moore and Hunt (2012) only found significant $\mathrm{C}$ accumulation $\left(84 \mathrm{~g} \mathrm{C} \mathrm{m}^{-2} \mathrm{yr}^{-1}\right)$ in the vegetated SW zones of CSWs in North Carolina. The C density values in the OW and SW zone herein exceeded that of Moore and Hunt (2012) in just one year. Long-term C assessments at this site are highly recommended to investigate accumulation rates and compare them to those found in previous studies. However, critical design features have been incorporated to promote long-term $\mathrm{C}$ sequestration. Planting and establishment of vegetation in the shallow water and temporary inundation zones of CSWs is vital to providing a C source to the soil (Pouyat et al., 2009). From a design perspective, ensuring the water levels are shallow enough to support emergent vegetation is important. This was achieved at the site by adjustable outlet structures and proper maintenance (Hunt et al., 2011; Merriman and Hunt, 2014). Constructed stormwater wetlands are typically found in poorly drained soils (U.S. NRCS hydrologic soil group C and D) and/or in low-lying environments with high water tables. A soil analysis is recommended to determine the viability of soils to assure healthy vegetation growth. At this CSW, the original topsoil was saved 
and redistributed spatially and incorporated into the top $10 \mathrm{~cm}$ of the soil surface to promote vegetation establishment. When designed with these techniques, Moore and Hunt (2013) found CSWs to be the only vegetated SCM to offset C emissions associated with materials, construction, and maintenance activities.

\section{Conclusions}

In this study, the ecosystem services development during the first two growing seasons - the 'ripening' period - was assessed of a CSW located on the coast of North Carolina. The following are principal conclusions:

o This CSW provided hydrologic mitigation services by significantly reducing runoff volume (54\%) through water storage and subsequent losses (ET and seepage) almost immediately after construction; as such ripening was instant. A large design area, underlying geologic conditions, and somewhat lengthy HRTs aided in these water losses.

o The CSW significantly reduced all pollutants for both flow regimes (Table 7). High $\mathrm{NO}_{2,3}$ and TSS treatment efficiencies were observed immediately and remained constant for the monitoring period, while others (TAN, ON, TN, and TP) had a ripening period of approximately 300 days post-construction, according to cumulative mass loadings (Figure 8).

o The overall establishment of vegetation (approximately $80 \%$ vegetative coverage) was complete by the end of the $1^{\text {st }}$ growing season, approximately 165 days. This CSW provided a biodiverse vegetative community by the peak of its $2^{\text {nd }}$ growing season (400 days), comparable to other CSWs in North Carolina (Moore and Hunt, 2012). 
o Overall, the \% C and areal $\mathrm{C}$ density for each hydrologic zone increased, indicative of $\mathrm{C}$ accumulation from the first to second year. Areal $\mathrm{C}$ density measurements for the $\mathrm{OW}$ (1090 $\mathrm{g} \mathrm{C} \mathrm{m}^{-2}$ ) and SW (1361 $\mathrm{g} \mathrm{C} \mathrm{m}^{-2}$ ) zones were on par with those found for other CSWs in North Carolina (Moore and Hunt, 2012), just one year due to rapid vegetation establishment.

o Overall, the establishment of vegetation was deemed the most important design goal, as vegetation drives or promotes many other services: evapotranspiration, water quality improvement, and $\mathrm{C}$ input to the soil. Several design characteristics and maintenance activities led to the rapid establishment of vegetation at this site. In addition to including three distinct hydrologic zones, the original topsoil was incorporated into the new topography, providing an organic matter source for vegetation, and water levels in the CSW were kept between $0-15 \mathrm{~cm}$ during the first two months by using adjustable outlet structures. This allowed the vegetation to establish before fluctuations in water levels started.

o Generally, there were no stark differences in ecosystem services development between the two flow regimes: event and base flow. Both flow regimes had improved water quality and rapid vegetation establishment, despite differences in hydroperiod and water levels.

o The full potential of some ecosystem services of this CSW were realized immediately such as volume reduction, TSS and $\mathrm{NO}_{2,3}$ treatment, while others were delayed and fully developed after the $1^{\text {st }}$ growing season: TAN, ON, TN, and TP treatment. Vegetation biodiversity and $\mathrm{C}$ sequestration service development was on par or exceeded that observed for other stormwater wetlands observed in North Carolina during the 515-day 
window of study for this CSW. This study demonstrates there is a synergistic ripening of hydrologic, water quality, plant biomass/biodiversity, and C sequestration services in CSWs and recommend regulators, practitioners, and researchers to view these systems holistically for future evaluation, metrics formation, and research endeavors.

\section{Acknowledgements}

The authors acknowledge the North Carolina Ecosystem Enhancement Program (Project Manager: Kristin Miguez) and the National Science Foundation for funding this study. The support from the City of New Bern staff, especially Matthew Montanye, Jordan Hughes, and Avery Smith, was vital. The authors also thank many members of the NCSU BAE Stormwater

Team (Shawn Kennedy, Alessa Smolek, Jessie Fears, Natalie Carmen, and Sarah Waickowski) for assistance with sample collection and analyses. Water quality analyses by Jenny James and Linda Mackenzie with the Center for Applied Aquatic Ecology at North Carolina State University is appreciated. Manuscript reviews by François Birgand, Michael Burchell, and Deanna Osmond are also greatly appreciated.

\section{References}

American Public Health Association (APHA), American Water Works Association (AWWA), and Water Environmental Federation (WEF). 2012. Standard Methods for the Examination of Water and Wastewater, $22^{\text {nd }}$ edn., American Public Health Association, Washington DC, USA.

Anderson, C.J. and Mitsch, W.J. 2006. Sediment, carbon, and nutrient accumulation at two 10year-old created riverine marshes. Wetlands, 26: 779-792.

Ardon, M., Montanari, S., Morse, J.L. Doyle, M.W., Bernhardt, E.S. 2010. The water quality consequences of restoring wetland hydrology to a large agricultural watershed in the 
southeastern coastal plain. Ecosystems, 13: 1060 - 1078.

Barrett, M.E., Lantin, A., and Austrheim-Smith, S. 2004. Stormwater pollutant removal in roadside vegetated buffer strips. Transportation Research Record 1980, Transportation Research Board, Washington, DC, $129-140$.

Birch, G.F., Matthai, C., Fazeli, M.S., Suh, J.Y. 2004. Efficiency of a constructed wetland in removing contaminants from stormwater. Wetlands, 24(2): 459-466.

Blake, G.R., Hartage, K.R. 1986. Bulk density. In: Klute, A. (Ed.), Methods of Soil Analysis Part 1: Physical and Mineralogical Methods $2^{\text {nd }}$ Edition. Soil Science Society of America, Madison, WI. pp. 363-375.

Bolund, P. and Hunhammar, S. 1999. Ecosystem services in urban areas. Ecological Economics, 29(2): $293-301$.

Bouchard, N.R., Osmond, D.L., Winston, R.J., Hunt, W.F. 2013. The capacity of roadside vegetated filter strips and swales to sequester carbon. Ecological Engineering, 54: 227-232.

Bruland, G.L., Richardson, C.J. 2006. Comparison of soil organic matter in created, restored, and paired natural wetlands in North Carolina. Wetlands Ecology and Management, 14: 245-251.

Buell, G.R., Makewich, H.W. 2004. Data compilation, synthesis, and calculations used for organic-carbon storage and inventory estimates for mineral soils of the Mississippi River Basin. In: Makewich, H.W. (Ed.), Soil-Carbon Storage and Inventory for the Continental United States. U.S. Geological Survey, Reston, VA.

Caldwell, P.V., Vepraskas, M.J., Skaggs, R.W., Gregory, J.D. 2007. Simulating the water budgets of natural Carolina bay wetlands. Wetlands, 27(4): $1112-1123$.

Costanza, R., d'Arge, R., de Groot, R., Farber, S., Grasso, M., Hannon, B., Limberg, K., Naeem, S., O’Neill, R., Paruelo, J., Raskin, R., Sutton, P., van den Belt, M. 1997. The value of the world's ecosystem services and natural capital. Nature, 387: 253-260. 
Craft, C.B., Reader, J., Sacco, J.N., Broome, S.W. 1999. Twenty-five years of ecosystem development of constructed Spartina alterniflora (Loisel) marshes. Ecological Applications, 9(4): 1405-1419.

DeGroot, R. 2006. Function-analysis and valuation as a tool to assess land use conflicts in planning for sustainable, multi-functional landscapes. Landscape Urban Planning. 75: 175-186.

Euliss, N.H., Gleason, R.A., Olness, A., McDougal, R.L., Murkin, H.R., Robarts, R.D., Bourbonniere, R.A., Warner, B.G. 2006. North American prairie wetlands are important nonforested land-based carbon storage sites. Science of the Total Environment, 361(1): 179 188.

Fuka, D.R., Walter, M.T., Archibald, J.A., Steenheius, T.S., Easton, Z.M. 2014. EcoHydRology: A community modeling foundation for Eco-Hydrology. R Package Version 0.4.12. url: http://CRAN.R-project.org/package=EcoHydRology

Ghermandi, A., van den Bergh, J., Brander, L., de Groot, H., Nunes. P. 2010. Values of natural and human-made wetlands: a meta-analysis. Water Resources Research, 46: W12516, doi:10.1029/2010WR009071.

Glenn, E.P., Mexicano, L., Garcia-Hernandez, J., Nagler, P.L., Gomaz-Sapiens, M.M, Tang, D., Lomeli, M.A., Ramirez-Hernandez, J., Zamora-Arroyo, F. 2013. Evapotranspiration and water balance of an anthropogenic coastal desert wetland: responses to fire, inflows, and salinities. Ecological Engineering, 59: 176 - 184.

Golubiewski, N.E. 2006. Urbanization increases grassland carbon pools: effects of landscaping in Colorado's front range. Ecological Applications, 16(2): 555-571.

Greenway, M. 2004. Constructed wetland for water pollution control - processes, parameters, and performance. Developments in Chemical Engineering and Mineral Processing, 12(5-6): 491 $-504$.

Greenway, M., Dale, P., Chapman, H. 2003. An assessment of mosquito breeding and control in four surface flow wetlands in tropical-subtropical Australia. Water Science and Technology, 
48(5): $249-256$.

Greenway, M., Jenkins, G., Polson, C. 2007. Macrophyte zonation in stormwater wetlands: getting it right! A case study from subtropical Australia. Water Science and Technology, 56(3): $223-231$.

Greenway, M. 2010. Wetlands and ponds for stormwater treatment in subtropical Australia: their effectiveness in enhancing biodiversity and improving water quality? Journal of Contemporary Water Research \& Education, 146: 22-38.

Haan, C.T., Barfield, B.J., Hayes, J.C. 1993. Design Hydrology and Sedimentology for Small Catchments. Academic Press Inc. San Diego, California, pp. 39-40.

Harrington, R., Dunne, E. J., Carroll, P., Keohane, J., and Ryder, C. (2005). "The concept, design and performance of integrated constructed wetlands for the treatment of farmyard dirty water." E.J. Dunne, K.R. Reddy, O.T. Carton (Eds.), Nutrient Management in Agricultural Watersheds: A Wetlands Solution, Wageningen Academic Publishers, Wageningen, The Netherlands: 179188.

Hathaway, J.M., and W.F. Hunt. 2010. An evaluation of stormwater wetlands in series in Piedmont, North Carolina. Journal of Environmental Engineering, 136(1): 140-146.

Hunt, W.F., Apperson, C.S., Kennedy, S.G., Harrison, B.A., Lord, W.G. 2006. Occurrence and relative abundance of mosquitos in stormwater retention facilities in North Carolina, U.S.A. Water Science and Technology, 54(6-7): 315 - 321.

Hunt, W.F., Burchell, M.R., Wright, J.D., Bass, K.L. 2007. Stormwater wetland design update. North Carolina Cooperative Extension, Raleigh, NC.

Hunt, W.F., Greenway, M., Moore, T.C., Brown, R.A., Kennedy, S.G., Line, D.E., Lord, W.G. 2011. Constructed stormwater wetland installation and maintenance: are we getting it right? Journal of Irrigation and Drainage Engineering, 137(8): 469-474.

Hutchinson, K.J. and Hesterberg, D. 2004. Dissolution of phosphate in a phosphorus-enriched 
Ultisol as affected by microbial reduction. Journal of Environmental Quality, 22: 1793 - 1802.

Kadlec, R.H. and Wallace, S.D. 2008. Treatment Wetlands, $2^{\text {nd }}$ Edition, CRC, Boca Raton, Florida.

Kaplan, D., Bachelin, M., Muñoz-Carpena, R., Chacón, W.R. 2011. Hydrological importance and water quality treatment potential of a small freshwater wetland in the humid tropics of costa rica. Wetlands, 31: $1117-1130$.

Li, H. and Davis, A.P. 2009. Water quality improvement through reductions of pollutant loads using bioretention. Journal of Environmental Engineering, 135(8): 567 - 576.

Line, D.E., Jennings, G.D., Shaffer, M.B., Calabria, J., Hunt, W.F. 2008. Evaluating the effectiveness of two stormwater wetlands in North Carolina. Transactions of ASABE, 51(2): 521 -528 .

Mao, L.M., Bergman, M.J., Tai, C.C. 2002. Evapotranspiration measurement and estimation of three wetland environments in the upper St. Johns river basin, Florida. Journal of the American Water Resources Association, 38(5): 1271:1285.

Maryland Department of Environment (MDE). 2015. Maryland's Stormwater Management Program. URL:

http://www.mde.state.md.us/programs/Water/StormwaterManagementProgram/SedimentandStor mwaterHome/Pages/Programs/WaterPrograms/sedimentandstormwater/home/index.aspx. Assessed: 01 October 2015.

McNett, J.K. Hunt, W.F., Osborne, J.A. 2010. Establishing stormwater BMP evaluation metrics based upon ambient water quality associated with benthic macroinvertebrate populations. Journal of Environmental Engineering, 136(5): 535 - 541.

Merriman, L.S., and Hunt, W.F. 2014. Maintenance versus maturation: constructed stormwater wetland's fifth year water quality and hydrologic assessment. Journal of Environmental Engineering, 140(10), 05014003.

Millennium Ecosystem Assessment (MEA). 2005. Ecosystem Services and Human Well-Being: 
Wetlands and Water: Synthesis. Millennium Ecosystem Assessment Report to the Ramsar Convention. World Resources Institute, Washington, D.C. Assessed 15 June 2015. http://www.millenniumassessment.org/en/index.html

Moore, T.L.C., and Hunt, W.F. 2012. Ecosystem service provision by stormwater wetlands and ponds - a means for evaluation? Water Research, 46: 6811-6823.

Moore, T.L.C. and Hunt, W.F. 2013. Predicting the carbon footprint of urban stormwater infrastructure. Ecological Engineering, 58: 44-51.

Moore, T.L.C., Hunt, W.F., Burchell, M.R., Hathaway, J.M. 2011. Organic nitrogen exports from urban stormwater wetlands in North Carolina. Ecological Engineering, 37(4): 589 - 594.

Nathan, R.J., and McMahon, T.A. 1990. Evaluation of automated techniques for base flow and recession analyses. Water Resources Research, 26(7): 1465 - 1473.

Natural Resources Conservation Service (NRCS). 2015. Web Soil Survey. URL:

http://websoilsurvey.sc.egov.usda.gov/App/WebSoilSurvey.aspx

North Carolina Administrative Code. 2008. Jordan Lake and Falls Lake Nutrient Strategy. 15 NCAC 02B, Session Law 2009-216, and Session Law 2009-484, Raleigh, NC.

North Carolina Climate Office (NCCO). 2015. Climate Normals and Historical Records. State Climate Office of North Carolina. Raleigh, NC.

North Carolina Department of Environmental and Natural Resources (NCDENR). 2009.

Stormwater best management practices manual. Raleigh, NC: N.C. Division of Water Quality.

Natural Resources Conservation Service (NRCS). 2013. Web Soil Survey. URL:

http://websoilsurvey.sc.egov.usda.gov. Assessed 26 July 2015.

Pier, B.M., Dresser, B.R., Lee, J.J., Boylen, C.W., Nierzwicki-Bauer, S.A. 2015. Ecological analysis before and after planting in a constructed wetland in the Adirondacks. Wetlands, 35: 611 
Pouyat, R. Yesilonis, I., Golubiewski, N. 2009. A comparison of soil organic carbon stocks between residential turf grass and native soil. Urban Ecosystems, 12(1): 45-62.

R Core Team. 2015. R: A language and environment for statistical computing, R Foundation for Statistical Computing, Vienna, Austria. url: http://www.R-project.org.

Reddy, K. R. and DeLaune, R. D. (2008). Biogeochemistry of Wetlands: Science and Applications. CRC Press. Boca Raton, FL.

Reddy, K.R., Kadlec, R.H., Flaig, E., Gale, P.M. 1999. Phosphorus retention in streams and wetlands: a review. Critical Reviews in Environmental Science and Technology, 29: 83-146.

Richards, R.P. 1999. Estimation of pollutant loads in rivers and streams: a guidance document for NPS programs. Heidelberg College. Tiffin, $\mathrm{OH}$.

Richardson, C.J., and Vymazal, J. 2001. Sampling macrophytes in wetlands. In: Radar, R.B., Batzer, D.P., Wissinger, S.A. (Eds.), Bioassessment and Management of North America Freshwater Wetlands. John Wiley \& Sons, New York, New York, pp. 339 - 354.

Rushton, B. 1996. Hydrologic budget for a freshwater marsh in Florida. Water Resources Bulletin: American Water Resources Association, 32(1): 13 - 21.

Shannon, C., Weaver, W. 1949. The Mathematical Theory of Communication. University of Illinois Press, Urbana.

Strecker, E.W., Quigley, M.M., Urbonas, B.R., Jones, J.E., Clary, J.K. 2001. Determining urban stormwater BMP effectiveness. Journal of Water Resources Planning and Management, 127(3): $144-149$.

Taha, H. 1996. Modeling the impacts of increased urban vegetation on the ozone air quality in the south coast air basin. Atmospheric Environment, 30(20): 3423 - 3430. 
Thornthwaite, C.W., and Mather, J.R. (1957). Instructions and tables for computing potential evapotranspiration and the water balance. Drexel Institute of Technology, Laboratory of Climatolgy, Centerton, N.J.

Tullis, S.P., Amanian, N., Waldron, D. 1995. Design of labyrinth spillway. Journal of Hydrologic Engineering, 121(3): 247-255.

USEPA. 1988. Design Manual for Constructed Wetlands and Aquatic Plant Systems for Municipal Wastewater Treatment. EPA 625/1-88/022. Center for Environmental Research Information Cincinnati, Ohio, USA.

Wadzuk, B.M., Rea, M., Woodruff, G. Flynn, K., Traver, R.G. 2010. Water quality performance of a constructed stormwater wetland for all flow conditions. Journal of American Water Resources Association, 46(2): 385 - 394.

Wetzel, R. 2001. Fundamental processes within natural and constructed ecosystems: short-term versus long-term objectives. Water Science and Technology, 44: $1-8$. 